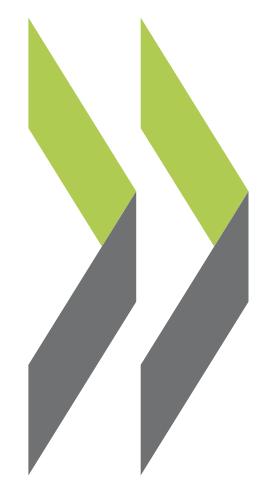

OECD Economics Department Working Papers No. 1120

\section{The Economic} Consequences of Ageing: The Case of Finland
Christine de la Maisonneuve,

Christophe André,

Clara García,

Vincent Koen 
Organisation de Coopération et de Développement Économiques

Organisation for Economic Co-operation and Development

03-Jun-2014

ECONOMICS DEPARTMENT

English - Or. English

THE ECONOMIC CONSEQUENCES OF AGEING: THE CASE OF FINLAND

ECONOMICS DEPARTMENT WORKING PAPERS No. 1120

By Christine de la Maisonneuve, Christophe André, Clara García and Vincent Koen

OECD Working Papers should not be reported as representing the official views of the OECD or of its member countries. The opinions expressed and arguments employed are those of the author(s).

Authorised for publication by Alvaro Pereira, Director, Country Studies Branch, Economics Department.

All Economics Department Working Papers are available through OECD's Internet website at http://www.oecd.org/eco/workingpapers

JT03358588

Complete document available on OLIS in its original format

This document and any map included herein are without prejudice to the status of or sovereignty over any territory, to the delimitation of international frontiers and boundaries and to the name of any territory, city or area. 
ECO/WKP(2014)16

OECD Working Papers should not be reported as representing the official views of the OECD or of its member countries. The opinions expressed and arguments employed are those of the author(s).

Working Papers describe preliminary results or research in progress by the author(s) and are published to stimulate discussion on a broad range of issues on which the OECD works.

Comments on Working Papers are welcomed, and may be sent to the Economics Department, OECD, 2 rue André-Pascal, 75775 Paris Cedex 16, France, or by e-mail to eco.contact@oecd.org.

This document and any map included herein are without prejudice to the status of or sovereignty over any territory, to the delimitation of international frontiers and boundaries and to the name of any territory, city or area.

The statistical data for Israel are supplied by and under the responsibility of the relevant Israeli authorities. The use of such data by the OECD is without prejudice to the status of the Golan Heights, East Jerusalem and Israeli settlements in the West Bank under the terms of international law.

(C) OECD (2014)

You can copy, download or print OECD content for your own use, and you can include excerpts from OECD publications, databases and multimedia products in your own documents, presentations, blogs, websites and teaching materials, provided that suitable acknowledgment of OECD as source and copyright owner is given. All requests for commercial use and translation rights should be submitted to rights@oecd.org 


\section{ABSTRACT/RÉSUMÉ \\ The economic consequences of ageing: the case of Finland}

Finland's population is set to age rapidly in the coming decades. This will put pressure on public finances, while shrinking labour resources. Nonetheless, solutions exist to alleviate those pressures. Adjusting the pension age in line with the rise in life expectancy would reduce pension costs and increase older workers' employment, provided it is accompanied by the removal of the pathways to early retirement. In order to allow people to work longer, labour market flexibility should be enhanced and lifelong training promoted further. Active labour market policies should be strengthened so as to increase the labour force participation of youth, childbearing age women and the long-term unemployed. Finally, ageing should not only be seen as a burden as it can also create opportunities for innovation and new markets and industries. Information and communications technologies, where Finland has a strong knowledge base, can help the elderly stay as autonomous as possible, which would contain long-term care costs and improve well-being.

This Working Paper relates to the 2014 OECD Economic Survey of Finland (www.oecd.org/eco/surveys/economicsurvey-finland.htm).

JEL Classification: H51, H55, J11, J14, J26.

Keywords: Ageing, Pensions, Health, Public finance, Labour market, Older workers, Finland.

$$
* * * * * * * * * * * * * * * * * * * * * * * * * *
$$

\section{Les conséquences économiques du vieillissement : le cas de la Finlande}

La population de la Finlande est en passe de vieillir rapidement dans les décennies à venir. Ceci devrait mettre sous tension les finances publiques et réduire les ressources en main-d'œuvre. Toutefois, des solutions existent pour alléger ces tensions. Ajuster l'âge du départ à la retraite pour tenir compte de l'allongement de l'espérance de vie permettrait de réduire les coûts des pensions et d'accroître l'emploi des travailleurs seniors, à condition d'être accompagné d'une suppression des passerelles vers la retraite anticipée. Pour que les individus puissent travailler plus longtemps, le marché du travail devrait être rendu plus flexible et la formation tout au long de la vie encouragée. Les politiques actives du marché du travail devraient être renforcées afin d'accroître le taux d'activité des jeunes, des femmes en âge de procréer et des chômeurs de longue durée. Enfin, le vieillissement de la population ne devrait pas être considéré comme un phénomène uniquement négatif, car il peut aussi est porteur de perspectives d'innovation et d'émergence de nouveaux marchés et de nouveaux secteurs d'activité. Les technologies de l'information et des communications, où la Finlande possède une solide base de connaissance, peuvent aider les personnes âgées à rester aussi autonomes que possible, ce qui permettrait de contenir les coûts des soins à long terme et d'améliorer le bien-être.

Ce Document de travail se rapporte à l'Étude économique de l'OCDE de la Finlande, 2014 (www.oecd.org/fr/eco/etudes/etude-economique-finlande.htm).

Classification JEL : H51, H55, J11, J14, J26.

Mots clés : Vieillissement, Retraites, Santé, Finances publiques, Marché du travail, Travailleurs âgés, Finlande. 


\section{TABLE OF CONTENTS}

THE ECONOMIC CONSEQUENCES OF AGEING: THE CASE OF FINLAND …................................... 6

A rapidly ageing population will put increasing pressure on public finances and labour resources........... 7

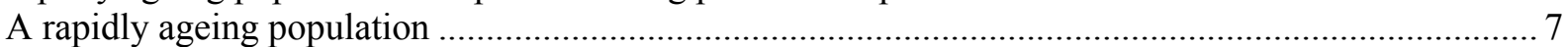

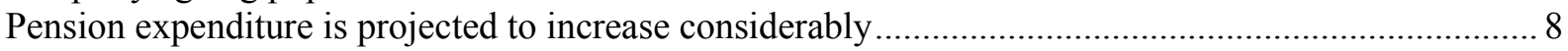
Pressure will also arise from health and long-term care ................................................................... 12

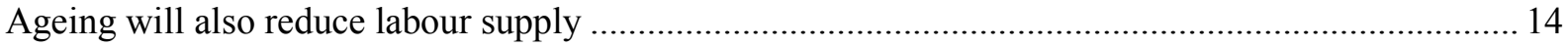

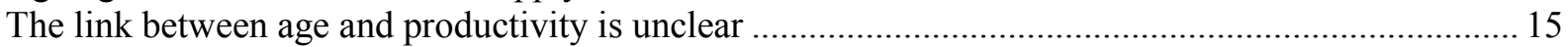

Solutions exist to adapt the pension and health systems to ageing .................................................... 16

Lengthening working lives seems to be the most consensual solution................................................ 16

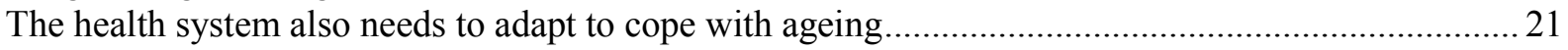

Measures should be implemented to help older workers stay at work or be hired................................. 23

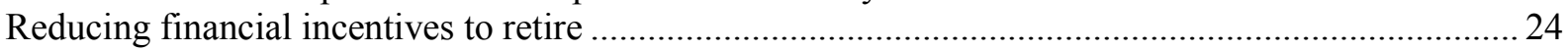

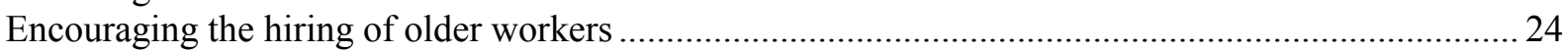

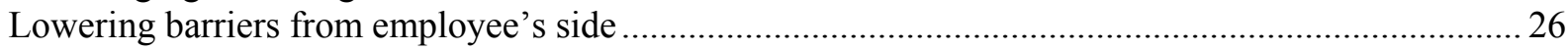

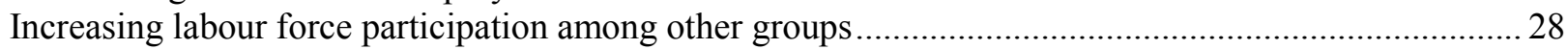

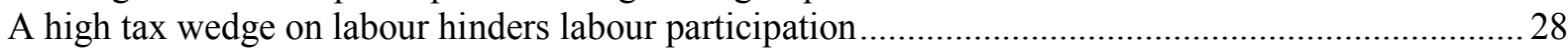

Youth, childbearing age women and long-term unemployed participation rates should be enhanced.. 28

More accommodative immigration policies would help cope with labour market shortages................29

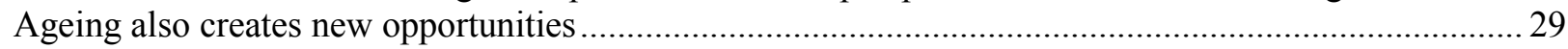

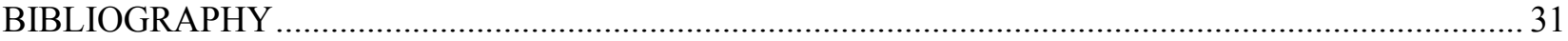

\section{Tables}

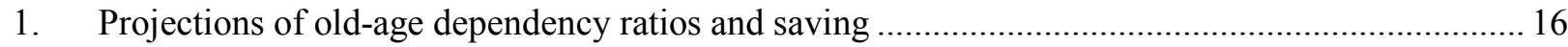

2. Pension ages needed to equalise benefits in 2010 and 2050 under different mortality scenarios.... 17

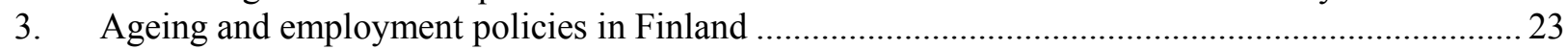

\section{Figures}

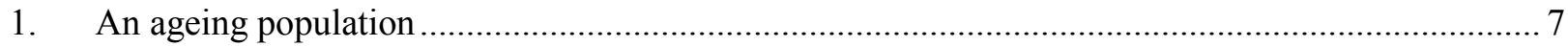

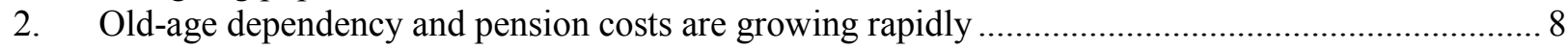

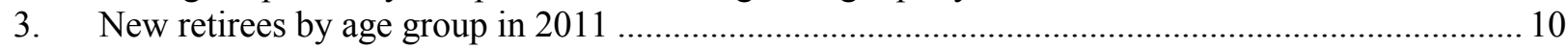

4. Average effective age of labour-market exit and normal pensionable age .................................... 11

5. Projected change in expected retirement duration at normal pensionable age................................. 12

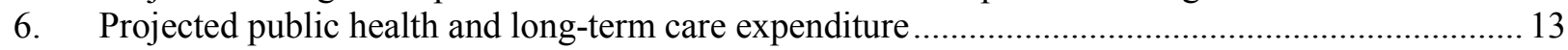

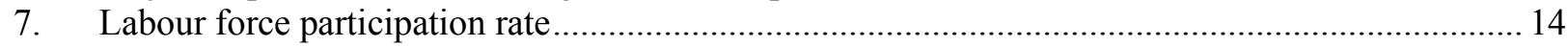

8. Pension entitlements under different life expectancy scenarios................................................. 17

9. Indexing the retirement age to life expectancy could stabilise labour force participation............... 19

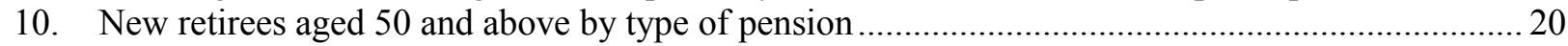

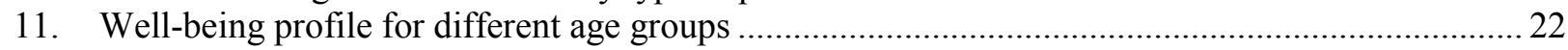

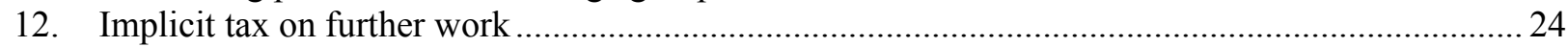

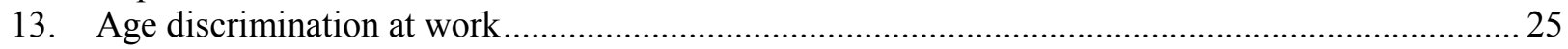

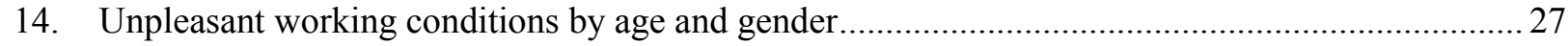

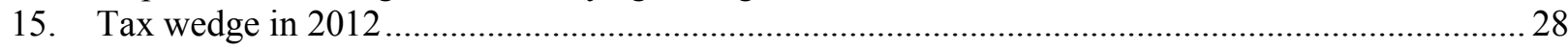


ECO/WKP(2014)16

\section{Boxes}

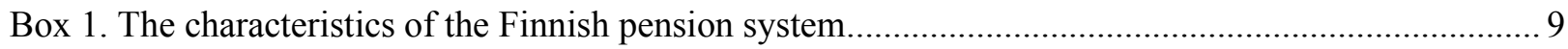

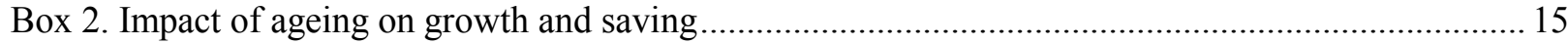

Box 3. Older Finns' well-being exceeds that of the overall population in many respects ....................... 22

Box 4. Recommendations on pension, health and labour market reforms ............................................ 30 


\title{
THE ECONOMIC CONSEQUENCES OF AGEING: THE CASE OF FINLAND
}

\author{
Christine de la Maisonneuve, Christophe André, Clara García and Vincent Koen ${ }^{1}$
}

Finland's population is set to age rapidly over the coming two decades, even more so than in other Nordic countries, the European Union (EU) and the OECD. The growing share of older people will put pressure on public finances. Absent further reform, the sustainability of the pension system would be jeopardised, as public expenditure on pensions is expected to increase considerably until 2060. Pressure on public finances will also arise from health and long-term care expenditure, which is also on course to increase markedly over the same period. Regarding long-term care, the increasing number of dependent people will require more carers. Ageing will also reduce labour supply, leading to potential labour shortages.

Nonetheless, solutions exist to address those issues. Rising life expectancy calls for longer working lives. The minimum retirement age should be indexed to longevity. This would alleviate pressure on the pension system and at the same time offset, at least partly, the labour shortages arising from population ageing. The pathways to early retirement should be reduced or abolished and measures to help older workers stay at work should be implemented. While financial incentives for early retirement need to be reduced, the employability of older workers should be enhanced and employers should be encouraged to hire and retain them. Employers often have negative perceptions towards older workers, related for instance to their supposed obsolete technological skills or lower productivity. At the same time, older employees often find that their working conditions are not good enough to keep on working after the minimum retirement age. Those issues should be tackled by providing lifelong training, reducing employment protection legislation, developing flexible working arrangements and reducing high implicit tax rates.

Ageing also creates new business opportunities, as it modifies the demand structure. As ageing is a global phenomenon, a competitive edge in age-related consumption growth areas would create a strong potential for exports. Information and communications technologies, where Finland has a strong knowledge base, can contribute to meeting the key challenge of helping the elderly stay as autonomous as possible.

The first section of this paper looks at the pressure population ageing will put on public finances and the labour market. The second section suggests pension and health system reforms to adapt to ageing. The third section then proposes labour market adjustments to enhance employment of older workers. The fourth

1. The authors are from the OECD Economics Department. This paper was originally produced for the 2014 OECD Economic Survey of Finland published in February 2014 under the authority of the Economic and Development Review Committee (EDRC) of the OECD. The authors would like to thank Hervé Boulhol, Andrew Dean, Robert Ford and other OECD colleagues, as well as officials from the Finnish government and the Finnish Centre for Pensions, for valuable discussions and comments on earlier drafts. Special thanks to Nadine Dufour and Mikel Iñarritu for excellent technical preparation. 
section discusses ways to increase labour force participation in other groups. The final section outlines growth opportunities offered by ageing.

\section{A rapidly ageing population will put increasing pressure on public finances and labour resources}

\section{A rapidly ageing population}

As in most OECD countries, the population is ageing rapidly in Finland, as a consequence of lower birth rates and higher longevity. The old-age dependency ratio, defined as the share of the population aged 65 and over relative to the population aged 15-64, has risen steadily from less than $15 \%$ in 1970 , to $25 \%$ in 2010 , and it is projected to exceed $45 \%$ by 2060 (Figure 1, Panel A). Even more strikingly, the share of people aged over 80 in the total population will increase from less than 5\% in 2010 to around $12 \%$ in 2050, when it will be among the highest in the OECD and larger than in other Nordic countries (Figure 1, panel B).

Figure 1. An ageing population
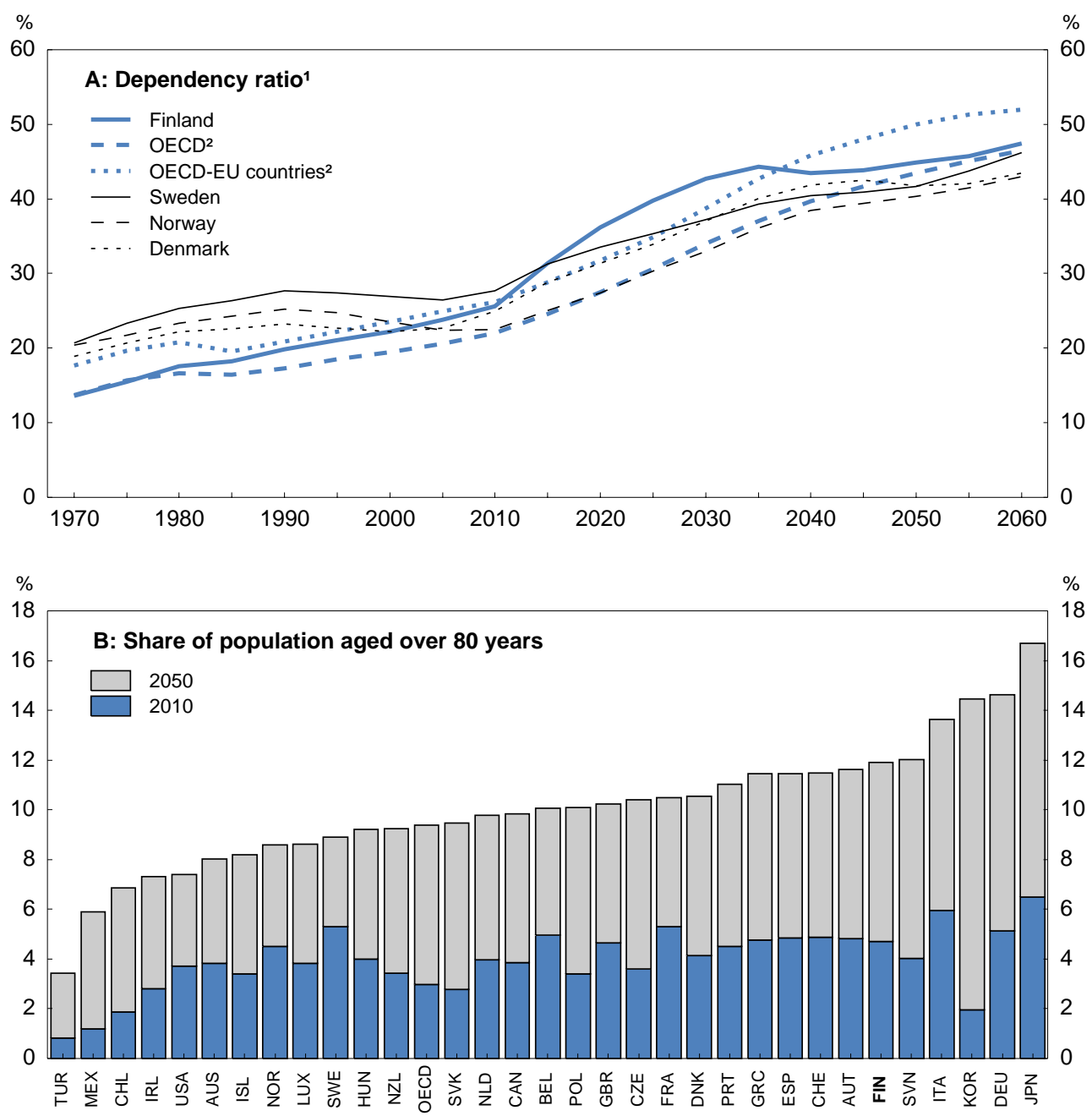

1. Population aged 65 and over relative to population aged $15-64$.

2. Weighted average.

Source: Eurostat, United Nations Population Division World Population Prospects: The 2013 Revision, and OECD Help wanted? Providing and paying for long-term care. 


\section{Pension expenditure is projected to increase considerably}

As a consequence of population ageing, pressure on the pension system will increase. The evolution of old-age and survivor pension expenditure differs across Nordic countries (Figure 2, Panel A). In Finland, this spending, starting from a rather moderate share of GDP, rose by around 3.5 percentage points between 1980 and 2009, reflecting a strong increase in the old-age dependency ratio. By contrast, the increase was around one percentage point of GDP in Denmark, Norway and Sweden, partly due to much lower demographic pressure. Moreover, Denmark and Sweden implemented pension reforms earlier than Finland.

Figure 2. Old-age dependency and pension costs are growing rapidly

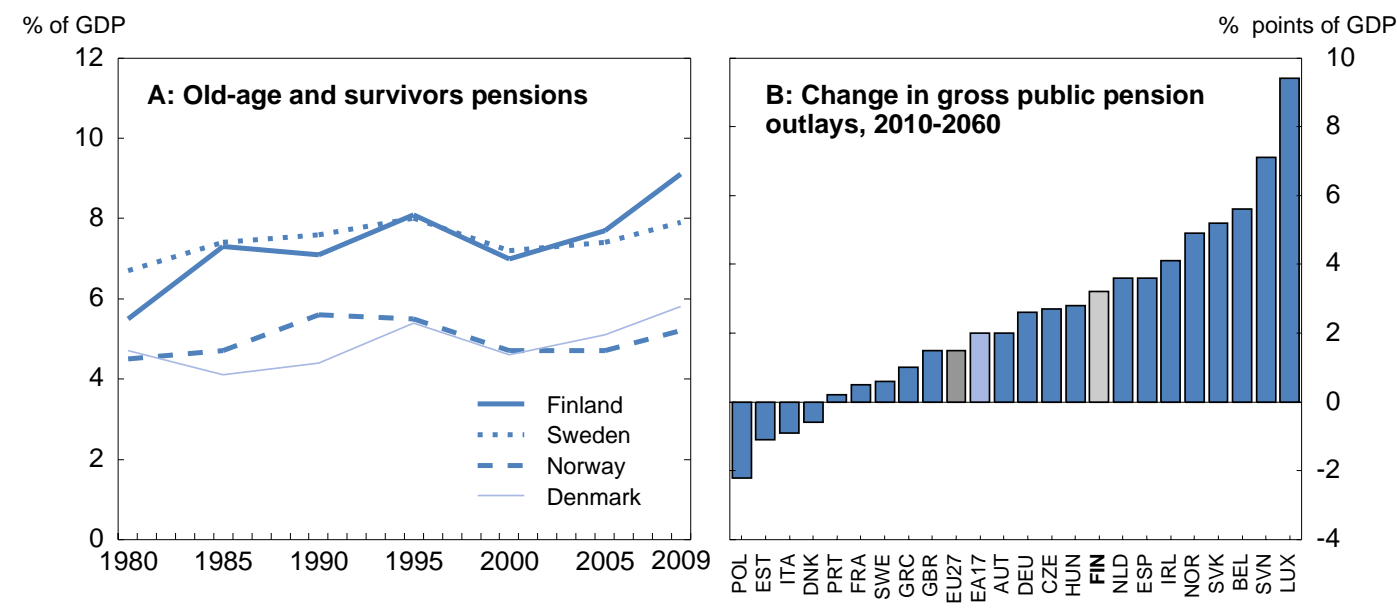

Source: OECD Social Expenditure Database and European Commission, The 2012 Ageing Report.

Going forward, the European Commission Economic Policy Committee's (EPC) baseline scenario (European Commission, 2012a) projects an increase in total public pension expenditure of more than 3 percentage points between 2010 and 2060, with a sharp rise before 2030 followed by relative stability between 2030 and 2060. This increase is higher than in Denmark, Sweden and the EU27 average, though less than in Norway (Figure 2, Panel B). While disability and survivor pension expenditure is expected to decrease as a share of GDP, old-age pension outlays are set to rise by about 4 percentage points.

The Finnish Center for Pensions expenditure projections are lower than the EPC's: total public pension outlays as a share of GDP are projected to increase by nearly 2 percentage points between 2012 and 2030 and then to decline by 1.2 percentage points to slightly less than $14 \%$ of GDP by 2060 . The difference mainly reflects higher assumed population growth, resulting from lower mortality and higher immigration, and a smoother wage path in the Finnish Centre for Pensions scenario.

\section{The Finnish pension system has been reformed successfully to bear these rising costs in the short run}

The pension system, which was reformed in 2005, comprises three pillars (Box 1). The first one is a non-contributory national pension based on residence in Finland or other EU countries. It is means-tested, financed from general taxation and paid by the central government. As the national pension is below the poverty line, it has been complemented since 2011 by the guarantee pension for people without or with only a small earnings-related pension. The importance of the national pension has decreased over time as the earnings-related pension system matured. On average across all ages, it accounts for $10 \%$ of pension income, with the remaining 90\% coming from earnings-related pensions (Barr, 2012). 
The second pillar, referring to compulsory earnings-related pensions, is a defined-benefit system financed by contributions paid by employers and employees, and is based on insurance policies provided by different pension funds. It is about one-quarter funded. The characteristics of the system are negotiated between the social partners and co-ordinated by the Finnish Centre for Pensions under the supervision of the Ministry of Social Affairs and Health and the Financial Supervisory Authority. Private and public employees are covered by different funds. Seven companies manage $95 \%$ of private sector pensions. Varma and Ilmarinen dominate the market, with over $70 \%$ of pension insurance companies' assets as of end-2011. Keva, an independent corporation governed by public law, covers public employees.

The pension funds can be firm-specific or group-specific. Total pension assets amounted to 155 billion euros as of end-March 2013, with the public sector funds representing 55 billion and the private sector 100 billion. Finnish pension funds now represent around $80 \%$ of GDP compared to less than 50\% in 2001. This far exceeds the unweighted OECD average of 34\% (in 2010). As Finnish private-sector pensions have been partly funded since 1962 - when the system came into force and well before many other European countries where such buffer funds were only established in the 1990s - the Finnish funds' accrued assets are higher. Pension assets must be invested profitably and securely by law. At the end of 2012 , the largest proportion of assets (38\%) was invested in shares while $36 \%$ were invested in bonds, $11 \%$ in other interest-bearing instruments, $11 \%$ in real estate and $4.5 \%$ in hedge funds.

\section{Box 1. The characteristics of the Finnish pension system}

The Finnish pension system comprises three pillars. The main one is the compulsory earnings-related pension system. It is complemented by a non-contributory national pension and individual private pension or life insurance schemes.

The earnings-related pension system covers all employed persons: employees, entrepreneurs (business owners) and self-employed. It provides old-age pensions, disability pensions and family pensions to widows and orphans. The pension rights are transferable. Since 2005, the pensions are calculated over the lifetime salary.

The maximum replacement rate with a constant salary is $71.5 \%$ at age 63 and $89.5 \%$ at age 68 . The average replacement rate of new pensions is $60 \%$, while the average replacement rate of all pensions is $50 \%$. Since 2005 , pension rights accrue at an annual rate of $1.5 \%$ of pensionable earnings at ages $18-52,1.9 \%$ at ages $53-62$ and $4.5 \%$ at ages 63-67. Pension rights are also accrued while studying, on parental leave and while unemployed.

The average pension insurance contribution is $22-23 \%$ of the salary, with $17 \%$ from employers and $5 \%$ from employees at ages $18-52$ and $6 \%$ at age 53 and above. Moreover employers need to contribute to a disability scheme. To determine the disability contribution component, large companies are divided into contribution categories based on the number of disability pension incidences in the company two years earlier. There are 11 contribution categories depending on the size of the disability risk. Each category contains a different experience-rated contribution. Disability contribution rates range between $0.09 \%$ and $4.95 \%$.

Past earnings are revalued at a rate reflecting price increases for $20 \%$ and earnings growth for $80 \%$. Earningsrelated pensions in payment are increased each year in line with the earnings-related pension index, which is a weighted average of price change $(80 \%)$ and wage change $(20 \%)$.

In 2005, Finland introduced a life expectancy coefficient to adjust starting pension benefits. It serves to limit the impact of rising life expectancy on pension expenditure. As life expectancy increases, this coefficient will reduce the amount of the monthly pension. However, it will not reduce the total amount that a pensioner will receive during retirement, provided he lives to the age corresponding to the increased life expectancy. The level of comparison is life expectancy in 2009 , for which the life expectancy coefficient was set at a value of one. It applied to people born in 1947 who retired in 2009. It decreases thereafter to reach 0.98 for people born in 1951 retiring in 2013. 
The third pillar relates to the individual private pension or life insurance schemes and is not as important as in most OECD countries. In 2010, the mandatory earnings-related pension comprised $86 \%$ of pension wealth, $4.4 \%$ of total contributions were for voluntary earnings-related pensions, and only $2.7 \%$ were for voluntary individual pensions (Barr, 2012). As there is no ceiling on the contributions and benefits of the compulsory system and as the earnings-related pension system provides wide coverage and good replacement ratios, there is very little incentive to participate in third pillar schemes. Moreover, high private pension insurance costs and changing tax subsidy policies may have hampered the development of the third pillar.

Since the 2005 reform, the official retirement age ranges between 63 and 68 for the second-pillar scheme. Figure 3 shows the age distribution of the individuals when they start drawing these pensions. There is a large spike in retirements at age 63, as most people draw their pension as soon as they can notwithstanding the increased accrual rate after 63 . The average effective age of retirement is even lower. Even if it has increased by nearly two years over the past decade, it is still below the official age, at 61.8 for men and 61.9 for women (Figure 4). The gap between the official and effective retirement age - taking 65 as the Finnish official retirement age, as it is the age at which the national and guarantee pension can be accessed - is among the widest in the OECD, far larger than in other Nordic countries. Nonetheless, four out of five Finns consider that working past the official retirement age should be allowed, and the same proportion would find it attractive to combine a part-time job with a partial pension instead of full retirement. This is higher than the EU average, which is at around two thirds. Even if financial incentives play an important role in the decision to retire, retirement choices are also driven by non-financial determinants related to individual background (e.g. health status, type of job, household situation), limited rationality, or socio-cultural and institutional factors (Van Erp et al., 2013).

Figure 3. New retirees by age group in 2011

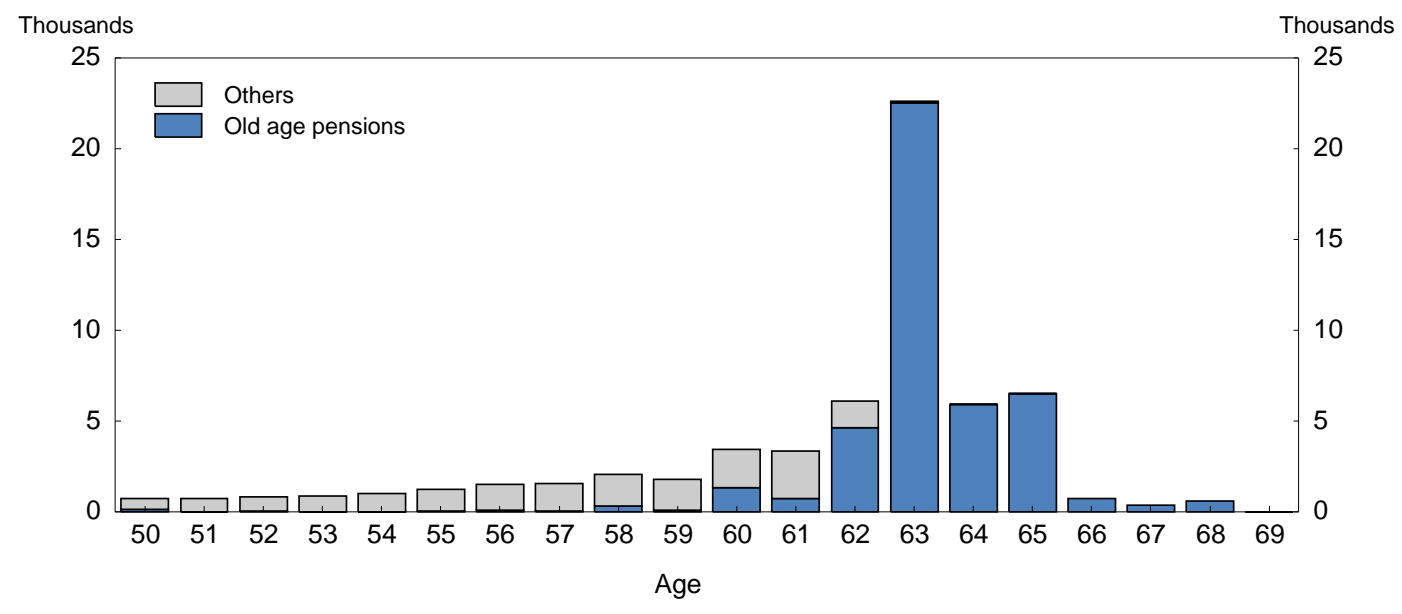

Source: Finnish Centre for Pensions. 
Figure 4. Average effective age of labour-market exit and normal pensionable age ${ }^{1}$

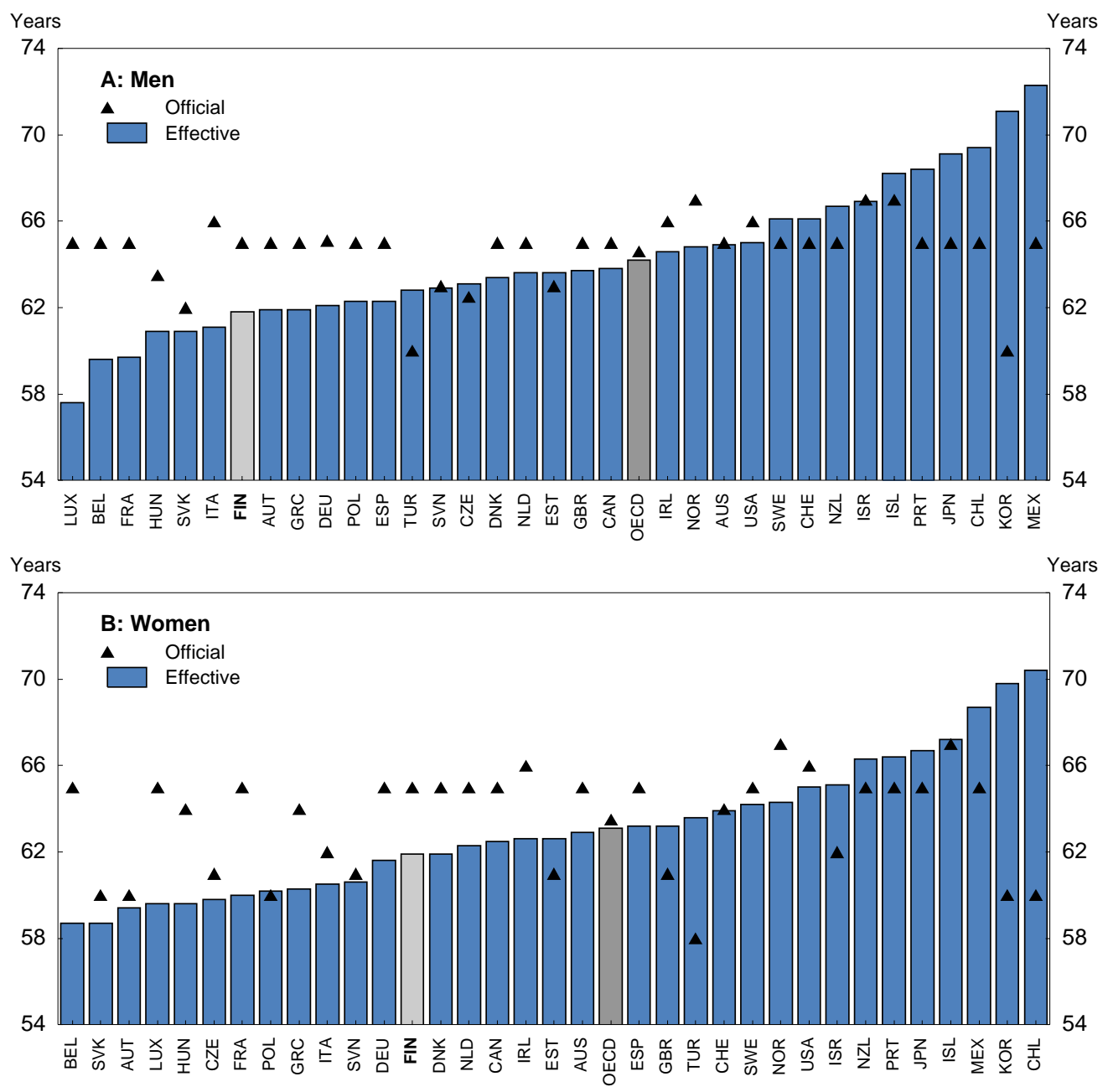

1. The effective retirement age shown is for the five year period 2007-12; the pensionable age shown is for 2012 .

Source: OECD (2013a), Pensions at a Glance.

\section{But increasing life expectancy will put the pension system under pressure}

Life expectancy increased significantly during the past decades, while the effective retirement age remained unchanged or has fallen in most OECD countries. Hence, the share of lifetime spent in retirement is increasing. Based on the life expectancy projections carried out by the United Nations Population Division and the pension age as planned under the current legislation, the OECD computes the expected retirement duration (OECD, 2011). Although no increase in the Finnish pension age has yet been legislated, the pension age is set at 65 until 2050. While, on average across OECD countries, the expected retirement duration at normal pensionable age is projected to increase by 1.9 (1.4) years for men (women) between 2010 and 2050, its increase for Finland is projected to amount to 3 (3.7) years (Figure 5). 
Figure 5. Projected change in expected retirement duration at normal pensionable age ${ }^{1}$

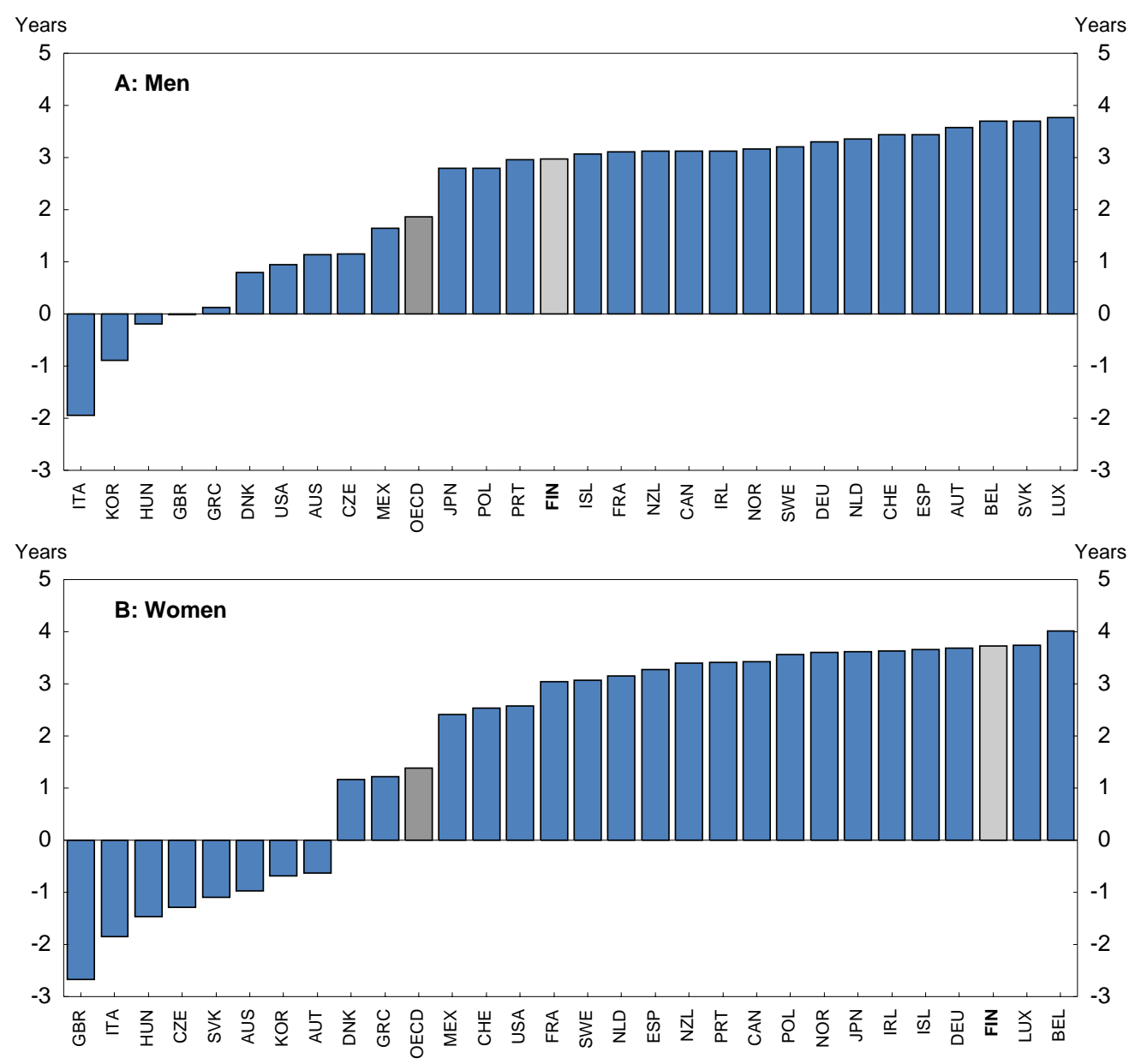

1. For Finland, the normal pensionable age is set at 65.

Source: OECD (2011), Pensions at a Glance.

\section{Pressure will also arise from health and long-term care}

Public spending on health and long-term care (LTC) has increased significantly over the past decade as a share of GDP, as in other Nordic countries. Since 1970, it has risen by nearly 3 percentage points to more than $6 \%$ in 2010 . Looking forward, the OECD projects that over the next 50 years it will increase by more than 2.5 percentage points to $8.6 \%$, even if policies act more strongly than in the past to rein in health and long-term care expenditures (Figure 6) (De la Maisonneuve and Oliveira Martins, 2013). In the absence of such policies, the expenditure ratio could more than double to reach 13\% of GDP in 2060 . Public health-care expenditure will be pushed up by both population ageing and non-demographic factors, such as increasing relative prices of health services and cost-increasing technological progress, with the latter factors taking the lion's share. 
Figure 6. Projected public health and long-term care expenditure

As a percentage of GDP

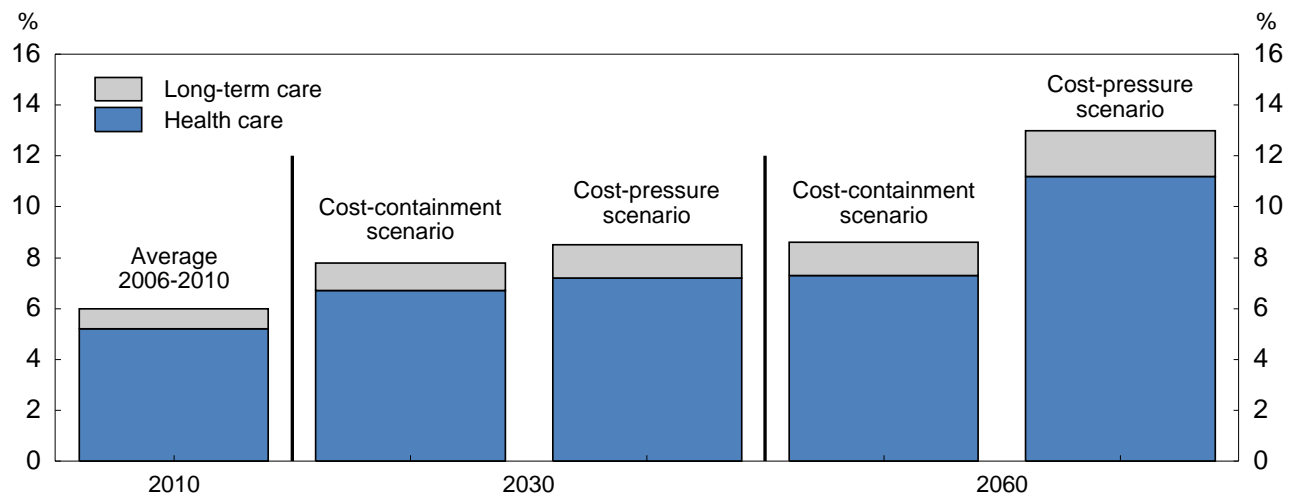

Source: De la Maisonneuve and Oliveira Martins (2013).

While demography is not the main driver of health care spending growth, it will induce a significant change in the structure of spending over time. In 2010, around $55 \%$ of health care expenditures were directed to people under 65 years old. It is projected that by 2060 more than $60 \%$ of expenditures will be directed to people aged over 65, reflecting an increase from $17 \%$ to $27 \%$ of their share in the population. This reflects demographic effects only, as non-demographic effects are assumed to affect all age groups in the same proportion. Inter-generational equity may thus be jeopardised at the expense of younger generations.

Growing needs for formal long-term care will contribute to the projected rise in total public health expenditure. This is largely due to the increase in longevity, as limitations in activities of daily life become increasingly common among people over 75 years old. In Finland, dementia is becoming more prevalent with the growth of the very old population ( 80 or more) and it is an increasingly common cause of death. The number of deaths caused by dementia more than doubled in two decades and represented around $20 \%$ of the total deaths of the elderly by 2011 (Statistics Finland, 2009; Forma et al., 2011). In the future, the increase in need for LTC is likely to be mitigated by healthy ageing (i.e. the translation of longevity gains into equivalent additional years without limitations in activities of daily life) through lifelong health prevention initiatives. However, three non-demographic factors are projected to push up LTC expenditure: increases in the relative price of LTC, rising incomes and changes in demand for publicly-financed LTC (which is likely to increase as informal care provided by the family declines with the increased labour force participation of older people, in particular women).

Rising relative prices due to rising unit labour costs of LTC services, which suffer from an inherent low potential for productivity gains, will be the major driver of expenditure. In the absence of costcontainment policies, the ratio of public LTC expenditure to GDP, starting from $0.8 \%$ of GDP in 2010 , is projected to increase by one percentage point by 2060. If cost-containment policies were implemented, the public LTC spending ratio would still increase by 0.5 percentage points between 2010 and 2060 . Since the 1990s, policies have succeeded in substituting service housing (housing with special care facilities, often including 24-hour assistance) for institutional care for a growing number of elderly people (OECD, 2012b). As institutional care is very expensive, the move towards service housing is likely to generate substantial savings, while improving the quality of life of old people. In addition, the National Memory Programme 2012-2020 aims at enhancing prevention, reducing stigma attached to memory disorders, enabling early diagnosis, improving treatments and developing research (Ministry of Social Affairs and Health, 2013a). This should both enhance well-being and reduce social welfare and health care costs. 


\section{Ageing will also reduce labour supply}

Ageing will also put pressure on the labour market. With a growing share of older workers in the labour force whose participation rate is rather low, the overall participation rate tends to decline. This has been the case for several years and is expected to continue for the next 50 years if no reform to increase participation is implemented (Figure 7, Panel A). The problem is much larger in Finland than in other Nordic countries. Starting at around $62 \%$ in the 1990 s, the labour force participation rate of people aged 15 and over is projected to decline by over 8 percentage points to $54 \%$ by 2060 . Labour force participation of people aged 55-64 has increased during the past decade and is in fact higher for those aged 55-59 than for the total working age population. Nevertheless, participation in the 55-64 age group, at just over 60\%, is still lower than in Denmark, Norway and Sweden (Figure 7, Panel B).

Figure 7. Labour force participation rate
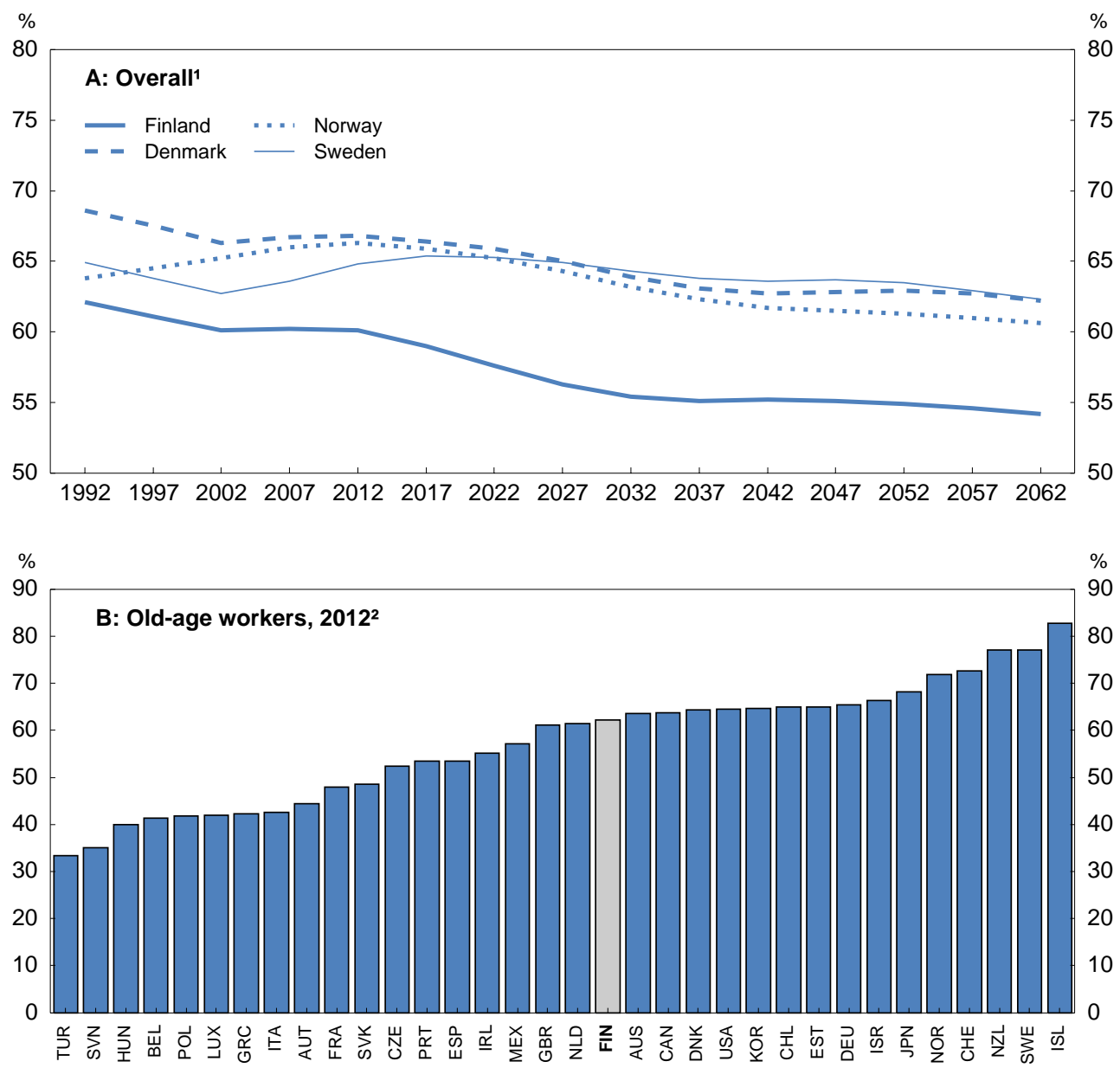

1. People aged 15 and over.

2. People aged 55-64.

Source: Johansson et al. (2013) and OECD, Labour Force Statistics. 


\section{The link between age and productivity is unclear}

Empirical evidence on the link between productivity and age is mixed. The OECD Survey of Adult Skills (PIAAC) finds that while Finland's adult population proficiency in literacy, numeracy and problem solving is among the highest in the 22 OECD countries participating in the Survey, the gap between younger and older age groups is wide. It should, however, narrow over time, as it mainly reflects spectacular progress in education over the past decades (OECD, 2013b). Surveys suggest that some physical and mental abilities decline from around the age of 50 (Skirbekk, 2003). In contrast, some verbal abilities and communicative skills remain more or less unchanged. Moreover, older workers can rely on their professional experience to adapt and compensate for declining abilities (OECD, 2006a).

A related, and potentially even more important, matter is the evolution of productivity relative to wages. If labour costs rise more steeply with age than productivity, firms will not want to retain or hire older workers (D'Addio et al., 2010). Mahlberg et al. (2013), using data for Austria, find no evidence that older workers are overpaid relative to their productivity. Likewise, Van Ours and Stoeldraijer (2010) find little evidence of an age related pay-productivity gap in the Netherlands. In contrast, Crépon and Aubert (2003) for France and Hellerstein and Neumark (2004) for the United States find that the decline in productivity after the age of 55 does not go along with a decline in relative wages. In Finland, OECD data show no evidence that wages exceed productivity for older workers (D'Addio et al., 2010).

At the macroeconomic level, scarcity of labour could push up wages, which would be an incentive to substitute capital for labour. Capital deepening would raise productivity. Nevertheless, it is unlikely that this effect would be sufficient to compensate for lower labour input in production. Hence, ageing should have a negative impact on growth (Box 2).

\section{Box 2. Impact of ageing on growth and saving}

Demographic trends, including ageing, shape the future path of labour and human capital and, in turn, GDP per capita (Johansson et al., 2013, and Bloom et al., 2011). Indeed, ceteris paribus, ageing will diminish labour supply and thus GDP growth. Age may also affect human capital: where older cohorts are less educated than younger ones, an older population will have, on aggregate, a lower level of education.

Using a Cobb-Douglas production function, the OECD projects long-term GDP as well as its determinants, namely physical capital, technical progress, human capital per worker and employment. Finland's potential GDP is projected to grow at an annual rate of $1.5 \%$ in $2012-17,2.1 \%$ in $2018-30$ and $1.4 \%$ in $2031-60$ (OECD, 2013c). While total factor productivity is the main driver, human capital is the second largest one. The baseline scenario assumes that over time each age-cohort has a constant level of human capital, corresponding to the level of schooling obtained at age 25-29. Reflecting past trends, educational attainment of the 25-29 age group is assumed to continue to gradually improve until reaching 18 years of schooling in 2100 .

Ageing may also have an impact on saving, which could affect investment and thereby productivity, innovation and ultimately income per capita. In fact, the old-age dependency ratio is one of the main determinants of saving (Kerdrain et al. 2010). This is consistent with the standard life-cycle hypothesis under which older people tend to have a lower propensity to save than people of working age (Modigliani and Ando, 1963). OECD projections show that Finland will experience a stronger increase in its dependency ratio and a larger decrease in its saving ratio than Sweden and Denmark (Table 1). Finland being a small open economy, the impact of lower saving on investment may be limited, as in such an economy interest rates are determined at the global level and are not affected by domestic saving (Sheiner et al., 2007). Nevertheless, reliance on foreign capital would increase, which could entail some risks, especially when financial markets are volatile. 


\begin{tabular}{|c|c|c|c|c|c|c|}
\hline & Finland & Sweden & Denmark & Finland & Sweden & Denmark \\
\hline & \multicolumn{3}{|c|}{ Old-age dependency ratio, in \% } & \multicolumn{3}{|c|}{ Total gross saving, in $\%$ of GDP } \\
\hline $2005-10$ & 24.8 & 27.0 & 23.8 & 23.6 & 26.8 & 23.7 \\
\hline $2025-30$ & 42.1 & 36.8 & 35.3 & 17.9 & 24.9 & 22.5 \\
\hline $2055-60$ & 45.9 & 45.5 & 41.9 & 16.2 & 22.0 & 21.6 \\
\hline Difference & & & & & & \\
\hline 2005-60 & 21.1 & 18.4 & 18.1 & -7.4 & -4.8 & -2.1 \\
\hline
\end{tabular}

\section{Solutions exist to adapt the pension and health systems to ageing}

Ageing will put pressure on public finances and labour supply. As regards public finances, reforms should be implemented to ensure the sustainability and adequacy of the pension and health systems. These reforms should go along with labour market adjustments to ensure that older workers can keep working.

\section{Lengthening working lives seems to be the most consensual solution}

As regards pensions, the question is about the share of the adjustment which should fall on the current contributors and retirees relative to future retirees. An intuitive approach is to achieve a long-term actuarial equilibrium, where the stream of expected future contributions and other revenues over a suitably long horizon (50-75 years) is enough to pay for projected benefits over that period. In countries like Finland, where large assets have been accumulated in pension funds, these need to be included in the calculation. To correct situations of actuarial disequilibrium, three parameters can be adjusted: pension eligibility ages; benefit levels; and contribution rates (OECD, 2012a).

As noted above, Finland chose in 2005 to index pension benefit levels to longevity via a life expectancy coefficient. In order to gauge the impact of such a reform, two measures of pension entitlements are useful. The first is the pension replacement rate which is the annual value of the benefit relative to individual earnings when working. The second is pension wealth, which is the present value of the lifetime flow of pension benefits (see OECD, 2011 for details on how these indicators are calculated). In a pure defined-benefit system, the same level of benefits is provided regardless of the evolution of life expectancy. This means that replacement rates are constant whereas pension wealth rises with life expectancy. For instance, a longer retirement duration implies higher lifetime benefits. Figure 8 shows the evolution of these two measures between 2010 and 2050 under different mortality scenarios for Finland and Slovenia, which both have public defined-benefit schemes. The two countries display different patterns as Finland has already introduced indexation of benefits to longevity, but Slovenia has not. As a pure defined-benefit system, Slovenia displays a constant replacement rate and higher pension wealth in lower mortality scenarios, where longevity increases. By contrast, Finland's replacement rate is reduced when longevity increases, and pension wealth is roughly constant. 
Figure 8. Pension entitlements under different life expectancy scenarios

Man with average earnings
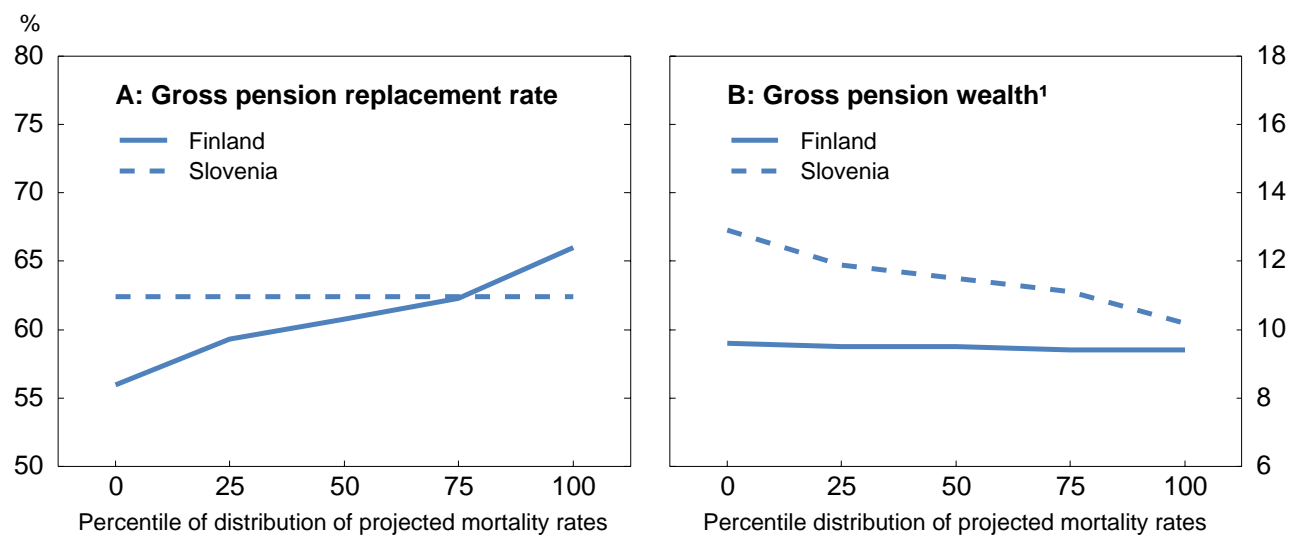

1. Pension wealth measures the total value of the lifetime flow of retirement incomes. It is expressed as a multiple of gross annual individual earnings.

Source: OECD (2011), Pensions at a Glance.

The life expectancy coefficient has been in place since 2010 and adjusts the level of pension benefits according to the future evolution of life expectancy (Box 1): the higher life expectancy, the lower the benefits. An obvious way to avoid a cut in pension benefits for an individual is to retire later. Working longer has three obvious advantages for public finances: it provides additional contributions, the benefit will be paid for a shorter period -- although this effect is partly offset by higher accrued pension rights -and higher employment will raise output, lowering the deficit. However, there is uncertainty regarding the extra working time needed to offset the decrease in pension levels and provide a constant replacement rate over time, as the future evolution of life expectancy is uncertain. The OECD calculated the pension age delivering an unchanged replacement rate in 2050 based on different assumptions regarding the evolution of mortality (OECD, 2012a). For Finland, starting from 65, the pension age is assumed to increase by 0.7 year in the high-mortality scenario, 2.3 years in the median-mortality scenario and up to 3.8 years in the low-mortality one, to almost 69 years (Table 2).

Table 2. Pension ages needed to equalise benefits in 2010 and 2050 under different mortality scenarios

Man on average earnings, selected countries

\begin{tabular}{lc|ccc}
\hline & \multirow{2}{*}{$\begin{array}{c}\text { Current normal } \\
\text { pension age }\end{array}$} & \multicolumn{2}{c}{ Pension age delivering equal replacement rate in 2050 } \\
\cline { 3 - 4 } & & Low mortality & Median mortality & High mortality \\
\hline Chile & 65 & 68.8 & 66.2 & 65.7 \\
Estonia & 63 & 64.2 & 63.7 & 63.3 \\
Finland & $65^{1}$ & 68.8 & 67.3 & 65.7 \\
Italy & 65 & 69.1 & 67.3 & 65.7 \\
Mexico & 65 & 68.7 & 66.2 & 67.7 \\
Norway & 67 & 60.9 & 69.6 & 65.7 \\
Poland & 65 & 68.7 & 67.7 & 65.4 \\
Portugal & 65 & 67.3 & 66.4 & 62.4 \\
Slovak Republic & 62 & 63.6 & 63.1 & 65.7 \\
Sweden & 65 & 68.8 & 67.4 & \\
\hline
\end{tabular}

1. National and guarantee pension can be accessed at 65 . The earnings-related pension age is 63 to 68 .

Source: OECD Pensions Outlook, 2012. 
ECO/WKP(2014)16

\section{The retirement age should be indexed to longevity}

As regards the life expectancy coefficient, there is no mechanism in place to ensure that people will compensate for the decrease in benefits by working longer. The life expectancy coefficient has only been in use for a few years and so far the associated adjustment has been small, hence its impact on retirement behaviour remains hard to quantify (Finnish Centre for Pensions, 2013). In half of OECD countries, the official retirement age for men is 65 (14 countries for women). Eight countries have an official age of 67 for men (seven for women). Finland allows people to retire on an old-age pension between 63 and 68 and currently experiences a sharp peak in retirements at age 63 . The minimum retirement age should be indexed to life expectancy to increase the effective retirement age. This recommendation is in line with the European Commission prescription. It will be more or less equivalent to raising the retirement age to 67 as in other EU (except France) and Nordic (except Sweden) countries by 2030, but automatic indexation will allow increasing the retirement age more smoothly. The upper retirement age limit should also be increased or abolished.

An alternative to indexing the retirement age only to life expectancy is to jointly adjust the retirement age and the level of pensions according to life expectancy gains. Adjusting these parameters has different consequences. While raising the minimum old-age retirement age forces people to work longer, adjusting the levels of benefits leads to lower pensions as benefits fall because people live longer. Indeed, benefits could decline by $15-20 \%$ for those drawing their pension in 2050 compared to 2010 (OECD, 2012a). The ensuing potential fiscal gains may be offset by additional expenditure on safety-net benefits.

Even though around half of OECD countries plan to increase their retirement age by 2030, only a few have linked the pension age to life expectancy. Denmark has indexed the retirement age to life expectancy after an initial increase to 67. From 2015, a five-year review of life expectancy will be carried out and the retirement age will be increased accordingly, but only after approval from the Danish Parliament. Greece and Italy have recently introduced reforms which allow indexation of the retirement age to life expectancy. France has introduced a kind of automatic adjustment, as the system aims at maintaining the ratio between the duration of activity and the expected duration of retirement constant.

Indexing the retirement age to life expectancy would boost labour force participation to the extent it raises the effective retirement age. In the context of the OECD long-term growth project, labour force participation projections were computed under unchanged policies as well as under the assumption of an indexation of the retirement age to longevity (Johansson et al., 2013). Under the second scenario, projected labour force participation is calculated so that "active life" remains constant as a share of life expectancy (Figure 9). For all OECD countries, indexing the age of retirement to longevity implies a higher overall participation rate in 2060 but the size of the gap between the two scenarios differs across countries. In Finland, starting from around $60 \%$, the overall labour force participation rate is projected to decline to around $53 \%$ in 2060 in the first scenario, whereas it is projected to stay constant in the second one. This is one of the widest gaps between the two scenarios in OECD countries and the largest among the Nordic countries. Indexation to life expectancy is therefore called for as soon as possible in Finland.

The modalities of indexation of the pension age, notably the ratio between the length of retirement and active life, should be decided by the government and the social partners. Although there are several ways to link the pension age to life expectancy, keeping active life constant as a share of life expectancy is the most widely accepted. Increasing the retirement age one for one with life expectancy gains would be a viable alternative only if each extra year in life expectancy translated into an additional year in good health. 
Figure 9. Indexing the retirement age to life expectancy could stabilise labour force participation ${ }^{1}$

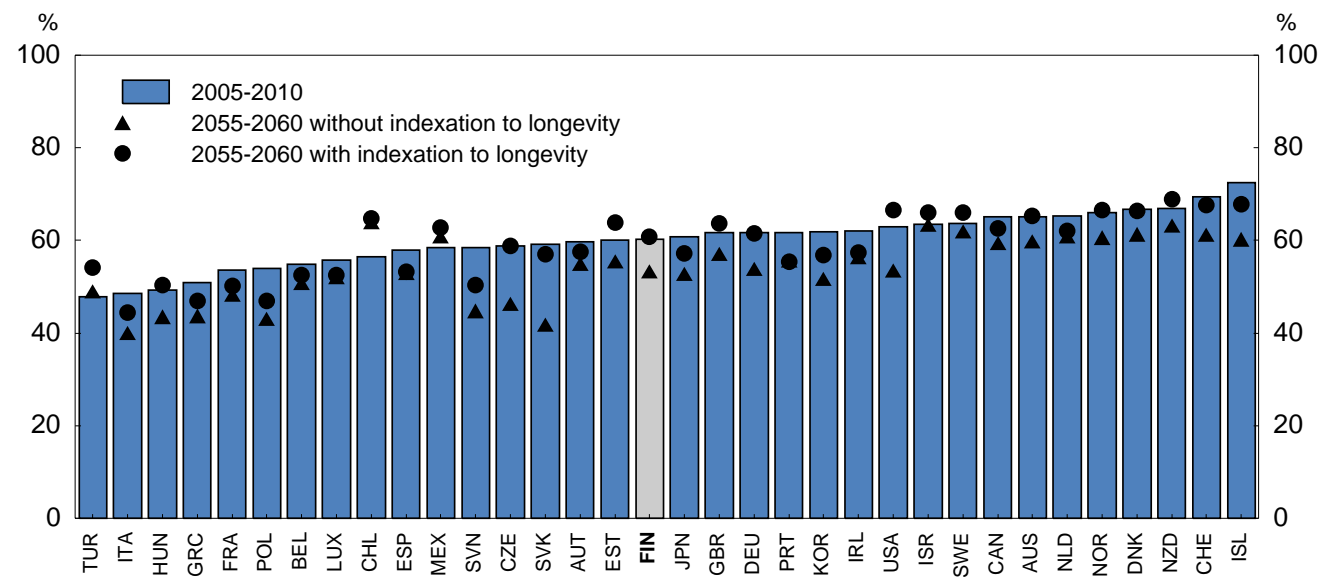

1. People aged 15 and over.

Source: Johansson et al. (2013).

However, life expectancy differs across occupational groups. Myrskylä et al. (2013) show that men's (women's) life expectancy in Finland at age 50 in 2007 was 31.5 (35.8) years for upper-level non-manual workers, while it was only 26.6 (32.9) years for manual workers. Moreover, since 1989, life expectancy has increased by 4 (3.4) years for men (women) upper-level non-manual workers, while it has only increased by 3.4 (2.9) for manual men (women). These trends are also observed in other countries. In the United Kingdom, men's life expectancy at age 65 is 2.6 years higher for the "Managerial and Professional" category than for "Routine and Manual" workers. This may need to be borne in mind during the negotiations on the modalities of indexation.

Nevertheless, policies should primarily focus on reducing health status disparities. Smaller reductions in mortality from cardiovascular diseases and - to a lesser extent - alcohol-related diseases, accidents and suicides in lower socio-economic groups have driven up inequalities. These trends are shared by other European countries but health inequalities seem to be particularly high in Finland, in contrast with income and education inequalities, which are among the lowest in the OECD (OECD, 2010 and 2012b). Efforts to reduce health inequalities have produced insufficient results so far. Prevention of risky behaviour and promotion of healthy lifestyles are part of broadly defined health policies. The merger of municipalities and the concomitant reform of the health system should also help reduce socio-economic health disparities and, as a consequence, reduce differences in future life expectancy (André and García, 2014).

\section{The pathways to early retirement should be reduced or abolished}

Since the 2005 reform, progress has been achieved in reducing early retirement. The unemployment pension has been abolished (Figure 10), but older people are still entitled to an extension of the period during which they receive the unemployment allowance. Under the Unemployment Security Act, a person who has turned 61 and has received an unemployment allowance for less than 500 days is entitled to the unemployment allowance until the start of the pension or until the age of 65 . This arrangement is much less generous than the one in place before the 2005 reform, which allowed a person on the average wage to retire at 55 with an initial replacement rate of about $60 \%$ (OECD, 2006b). Even so, this entitlement to unemployment benefits, the so-called "unemployment tunnel", still encourages older workers to give up active job search. 
This scheme and part-time pensions, which are heavily subsidised, are impediments to longer working lives. Part-time pensions can be granted if an individual transfers from full-time work to part-time work and doesn't receive any other pension based on his work history. According to a report from the Prime Minister's Office (2011), raising the minimum retirement age by two years and abolishing the unemployment tunnel and part-time pensions would imply an increase in the effective retirement age of 8.4 months in 2025. Assessing a similar reform, Määttänen (2013) finds an increase of 10 months. On the other hand, if the retirement age is raised without abolishing the pathways to early retirement, working lives are not lengthened, as people use these pathways instead of working longer. This suggests that both the unemployment tunnel and part-time pensions should be abolished.

Figure 10. New retirees aged 50 and above by type of pension

As a share of total pensions, excluding part-time pensions

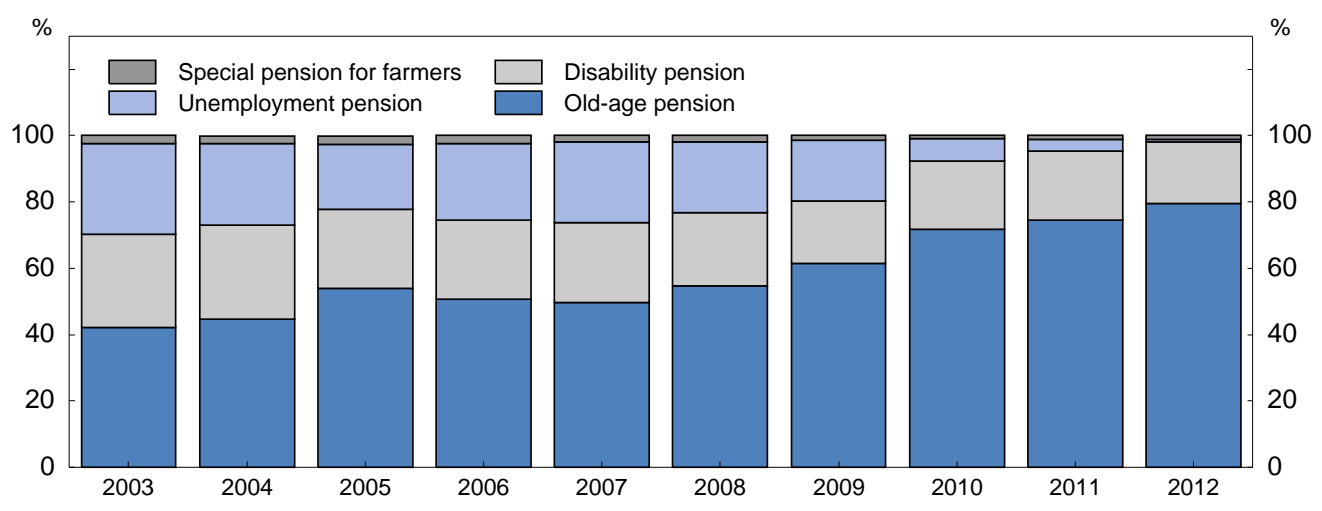

Source: Finnish Centre for Pensions.

Access to disability benefits offers another pathway to early retirement. Since the 2005 reform, while the individual early retirement pension has been abolished, there is a possibility to get a disability pension under less strict criteria from the age of 60. While the share of claim rejections has increased and the share of new retirees being granted a disability pension has decreased by nearly 10 percentage points, still more than $20 \%$ of new retirees leave the labour force on a disability pension. In terms of expenditure, the share of disability pensions in total pensions fell from more than $18 \%$ in 2003 to about $13 \%$ in 2011 . Access to disability pensions should be based on medical reasons only. Shifting the initial medical evaluation away from patients' physicians towards insurance teams would help achieve greater consistency and increase focus on medical conditions (Braconier, 2010).

\section{Lengthening working life could also be achieved at the beginning of the career}

Finnish students tend to enter the labour market relatively late. Indeed, the transition from school to work is one of the longest among Nordic countries. In Finland, around 16\% of youth aged 20-24 are neither in education or training nor in employment, as against 14\% in Sweden, 12\% in Denmark and 9\% in Norway. As regards the 25-29 year-olds, this share is even higher, amounting to nearly $17 \%$. Reducing delays in graduation and shortening the transition period from school to work would allow people to contribute longer to the pension system (OECD, 2010). The Government has announced measures such as shortening the period during which students are eligible to receive financial support from September 2014, a reformed selection process for higher education and a reform of the home-care allowance (Government of Finland, 2013). Revising public sector hiring requirements, so that a Bachelor's degree would be sufficient for certain positions, would also allow some youth to enter the labour market earlier. Moreover, measures should be taken to reduce the youth unemployment rate (see below). Incentives should also be enhanced to encourage young inactive people to enter the labour market. 


\section{Other means to adjust the Finnish pensions system are not optimal}

Another way to adjust the pension system would be by increasing the income of pension funds, via higher contribution rates. But contributions in Finland are already high by international standards and the wedge between the labour costs borne by the employer and the corresponding net take-home pay of the employee is high, reducing employment incentives (see below). Alternatively past earnings could be revalued in the calculation of future benefits. In most OECD countries, past earnings are raised in line with economy-wide wage growth for the purpose of benefit calculation. In Finland, the system indexes a worker's past earnings for $20 \%$ to prices and $80 \%$ to earnings, which is generally less costly. A further move towards a less generous revaluation procedure may jeopardise the adequacy of the system, by lowering benefit levels excessively. Finally the pension system can be improved by adjusting the growth of benefits received by current pensioners. They are now indexed for $20 \%$ to wages and $80 \%$ to prices, while, before the 2005 reform, the weights were $50 \%$ for both wages and prices. This evolution is in line with other OECD countries which have reformed their system towards less generosity in order to reduce costs.

The Finnish government has already started negotiations with the social partners about further reforms to be implemented in 2017. A target is to raise the effective retirement age to 62.4 by 2025 , but the means to reach this goal have not been specified. According to the latest long-term projections, under current rules, the effective retirement age is expected to reach 61.5 in 2015. In March 2012, the social partners agreed on two immediate amendments: an increase in the minimum part-time retirement age to 61 and to raise the age limit for eligibility to extended unemployment benefits from 60 to 61 for persons born in 1957 or later.

\section{The health system also needs to adapt to cope with ageing}

Even though the Finnish health care system offers good quality treatment at a fairly moderate cost, its efficiency could be improved, in particular by reducing fragmentation and improving coordination, and strengthening incentives to achieve a better balance between primary and specialised care. Narrowing regional differences in the efficiency and quality of care should also be a priority (see the special chapter on health care in the 2012 OECD Economic Survey of Finland). Information and communication technologies are powerful tools to improve the efficiency and quality of health care. Finland is one of the leading countries in the development of e-health, along with Denmark, and considerable progress has been made in standardising data over recent years, resulting in particular in the creation of lifelong electronic patient records for all Finnish patients. Such an information system has huge potential in terms of enhancing the integration of health and social care, improving care pathways and managing chronic diseases, which remains to be fully exploited (Ministry of Social Affairs and Health, 2013b). Municipal mergers and the associated reorganisation of health care services will help achieve significant efficiency gains (André and García, 2014). Enhancing the efficiency of the health system will help cope with the burden of ageing and will improve equity in access to health care. This should improve the health status of many individuals, raising labour supply as those in good health are more productive, less often on sick leave and enjoy better opportunities to build up human capital. The chances that they retire early are reduced, and as older people remain in good health for longer it reduces the burden of care on their relatives, who are more likely to take up a job.

Long-term care should be provided in the most cost-effective way. The ongoing shift from institutional care towards service housing should lower costs and improve the quality of life of old people. The Ministry of Social Affairs and Health estimates that lowering further the number of over 75-year olds in long-term institutional care would reduce municipal health care costs by around $€ 300$ million per year by 2017 ( $0.15 \%$ of GDP). Helping people to stay as autonomous as possible will contribute to maintaining or even improving the level of well-being elderly Finns enjoy today (Box 3). 


\section{Box 3. Older Finns' well-being exceeds that of the overall population in many respects}

As shown in the Assessment and Recommendations, Finland performs well in international comparison in all dimensions of well-being. Nonetheless, life satisfaction has slightly declined between 1981-84 and 2005-08 (World Values Survey, Gallup World Poll). During the same period, self-assessed health has worsened, while it has improved in the OECD as a whole (OECD, 2012b). These results relate to the Finnish population as a whole. In the context of an ageing society, it is useful to look at age-specific results. Recent literature argues there is evidence that well-being is U-shaped through the life cycle (Blanchflower and Oswald, 2007).

The well-being of older people in Finland compares favourably to EU countries, according to a recent study that provides a broad view of the well-being of older people (HelpAge International, 2013). In addition, the New Economics

Figure 11. Well-being profile for different age groups ${ }^{1}$ 2007

All ages

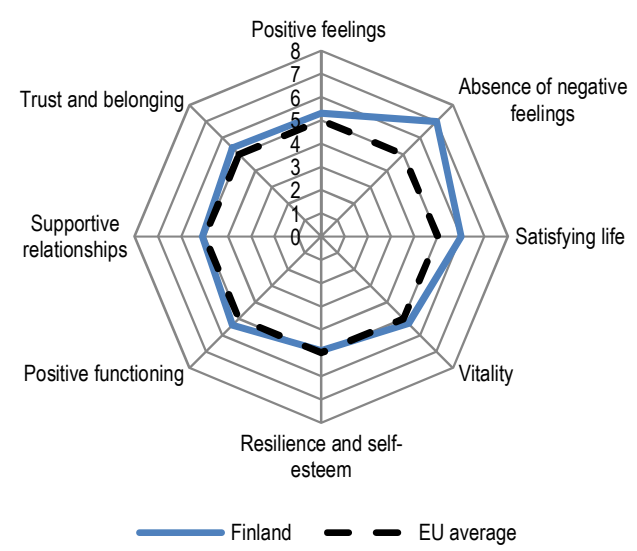

65 to 74

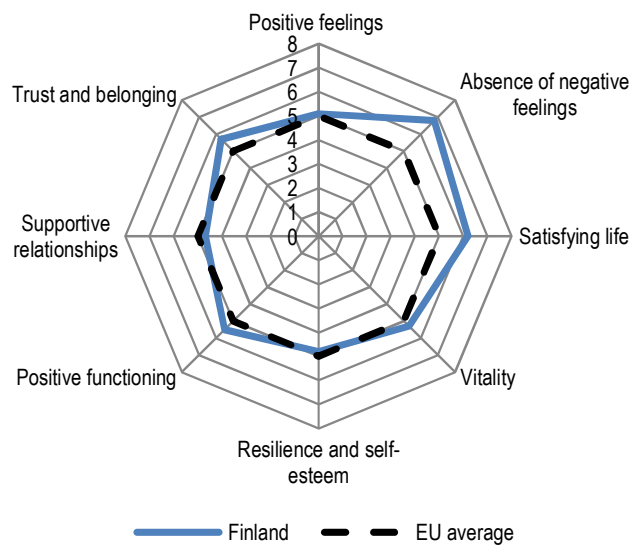

50 to 64

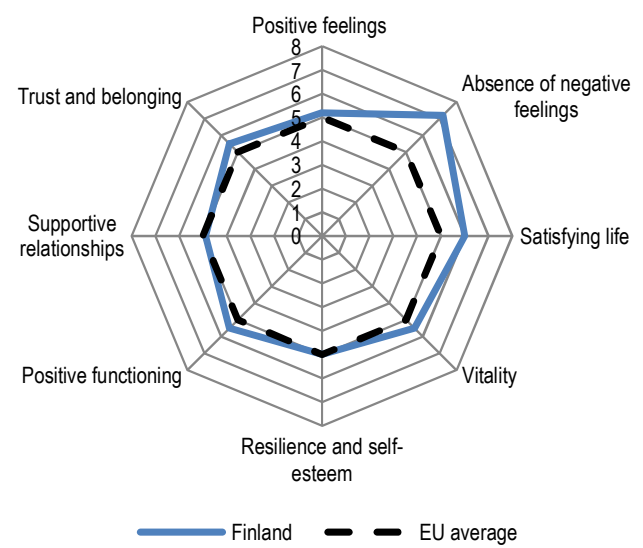

75 and over

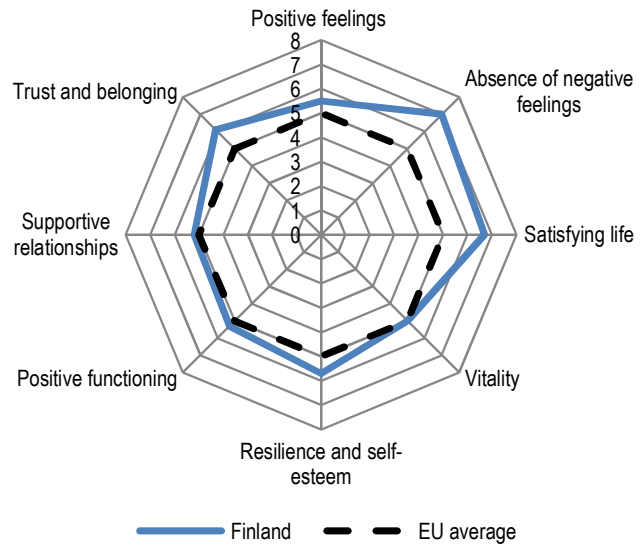

1. Indicators are normalised to range between 10 (best) and 0 .

Source: The New Economics Foundation, National Accounts of Well-being.

Foundation (NEF) computes some age-specific well-being indicators, which can be classified into personal and social. The former include positive feelings; absence of negative feelings; satisfying life; vitality, resilience and selfesteem; and positive functioning. The latter comprise supportive relationships; and trust and belonging. 
According to the NEF survey, for the population as a whole, Finland performs slightly better for the personal indicator (ranking $5^{\text {th }}$ out of $23 \mathrm{EU}$ countries) than for the social one ( $9^{\text {th }}$ out of 23 ). Finland scores close to the EU average for almost all components of well-being, and substantially above average for absence of negative feelings and satisfying life. This profile broadly applies to all ages. Interestingly, people aged 75 and over perform relatively better on satisfying life, resilience and self-esteem, and trust and belonging than the average of the population and the EU average (Figure 11).

\section{Measures should be implemented to help older workers stay at work or be hired}

The strong skills of Finnish workers highlighted in the PIAAC survey should ease the transition to longer working lives (OECD, 2013b). Nonetheless, lengthening working lives cannot be achieved without reforming some parts of the labour market. Indeed, even if there are some financial incentives to work longer (e.g. an increased accrual rate after 63), they may not be sufficient to keep people at work. Older workers face a range of work disincentives and barriers to employment which need to be removed. Employers are often reluctant to hire or retain them. Moreover, older workers are frequently discouraged from staying in work owing to poor working conditions.

Table 3. Ageing and employment policies in Finland

OECD's recommendations to Finland in 2004

Action taken by mid-2012

\section{A. Strengthening financial incentives to carry on working}

Review the proposal to extend the duration of unemployment benefits

Tighten job search requirements for receiving unemployment benefits

Review the proposed easing of eligibility rules for receiving disability benefits

Abolish the subsidy of part-time pensions

\section{B. Tackling employment barriers on the side of employers}

Remove the age-related component of social security contributions and review the system of experience-rating

Continue to promote age management training and information campaigns

Review the implementation of anti-age discrimination legislation

\section{Improving the employability of older workers}

Encourage upgrading of education levels and participation in lifelong learning

Arrange for working time to leave room for training

Establish quantitative goals for future government programmes

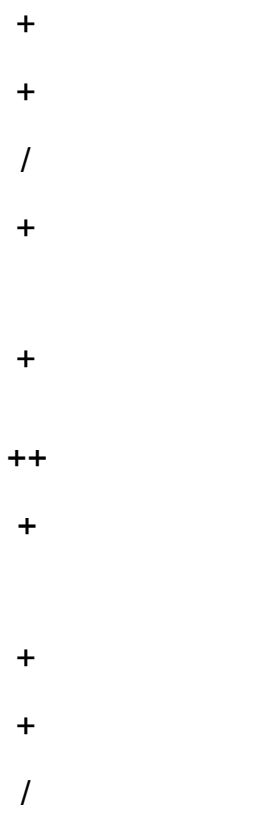

Notes:

I = no (relevant) action has been taken; + = some action has been taken, but more could be done; ++ = substantial action has been taken.

Source: OECD (2004), Ageing and Employment Policies: Finland and answers to the follow-up questionnaire from Finland (http://www.oecd.org/els/emp/Older\%20Workers\%20Finland-MOD.pdf).

In 2004, the OECD published a survey that took stock of employment policies implemented to address ageing (OECD, 2004). Recommendations were provided to enhance the employability of older workers. They covered three main areas: strengthening financial incentives to continue working, tackling employment barriers on the side of employers and improving the employability of older workers. A 
follow-up of this survey for Finland published in mid-2012 assesses progress in these areas since 2004 (Table 3). This shows that further improvement is needed in many areas.

\section{Reducing financial incentives to retire}

Reducing relatively high implicit taxes on continued work would encourage older people to continue working. If working an additional year yields increases the present value of the future stream of pension payments less than foregone pensions and contributions paid during that year, there is an implicit marginal tax on continued work (Duval, 2003). Implicit taxes on continued work are still higher in Finland than in other Nordic countries, contributing to low employment rates among older workers. Moreover, in contrast to the other Nordic countries, these implicit taxes have increased since 2007 (OECD, 2013d). During the window of retirement, namely between the age of 63 and 67, the implicit tax on further work increases (Braconier, 2010) (Figure 12).

Figure 12. Implicit tax on further work ${ }^{1}$

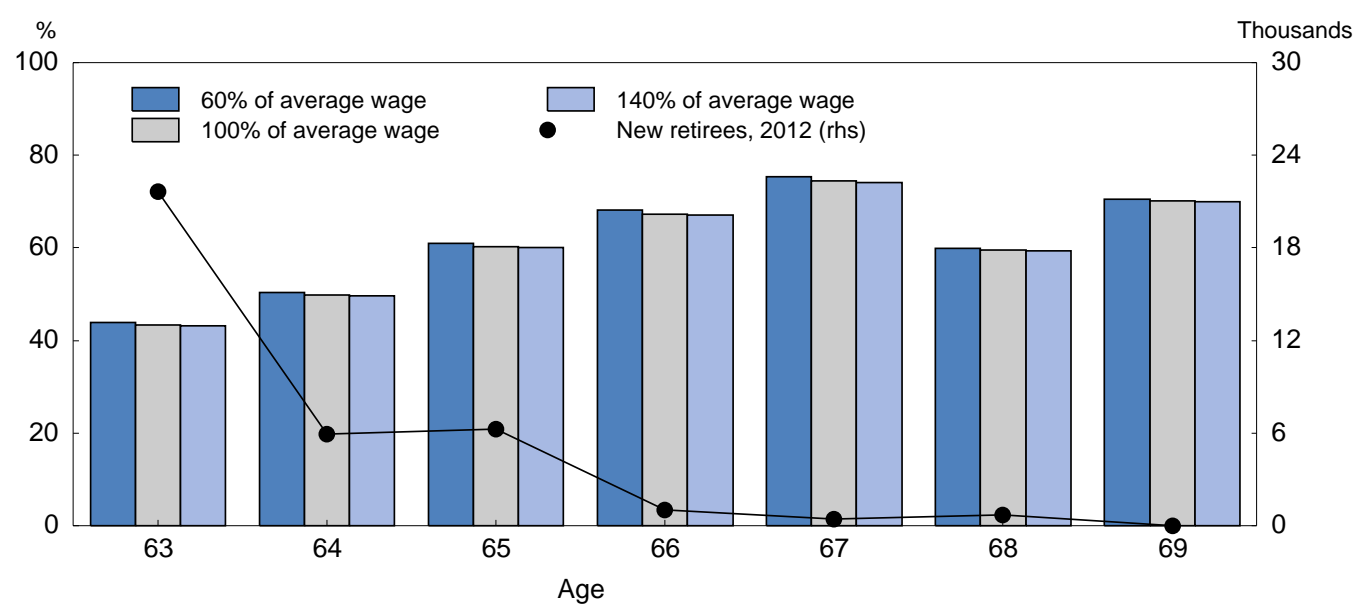

1. Implicit gross tax on working one additional year for an individual at $60 \%, 100 \%$ and $140 \%$ of the average wage instead of taking out an old-age pension.

Source: Braconier (2010).

\section{Encouraging the hiring of older workers}

Increasing older workers' employment rate depends as much on employer as on employee behaviour. In almost all OECD countries, surveys suggest (at least perceived) age discrimination on the part of employers. Around two thirds of Finns believe that negative perceptions by employers towards older people are an important factor for stopping work - around 10 percentage points above other Nordic countries. Around $60 \%$ believe that a job applicant aged over 55 is at a disadvantage. Around $7 \%$ of workers older than 55 have faced age discrimination in the workplace, more than in other Nordic countries (Figure 13). Older workers are perceived as having low technological skills and lacking openness to new ideas. However, they are generally seen as more reliable and productive, and as better decision-makers and problem-solvers than their younger counterparts (European Commission, 2012b).

In addition to anti-discrimination legislation based on international human rights agreements, Finland has put in place programmes to help employers manage the "greying" of their labour force: The Veto Programme (2003-07) implemented by the Ministry of Social Affairs and Health (MSAH), the Finnish Workplace Development Programme TYKES (2004-09), the Finnish Development Strategy of Working Life (2012) and a Forum for Well-being at Work (2008-11) put in place by the MSAH and which is being 
developed further in 2011-15 under a new strategy, Socially Sustainable Finland 2020. These programmes aim at promoting age management to extend and improve working lives. Even if some progress has been accomplished regarding age discrimination, the implementation of the legislation still needs to be monitored.

Figure 13. Age discrimination at work ${ }^{1}$

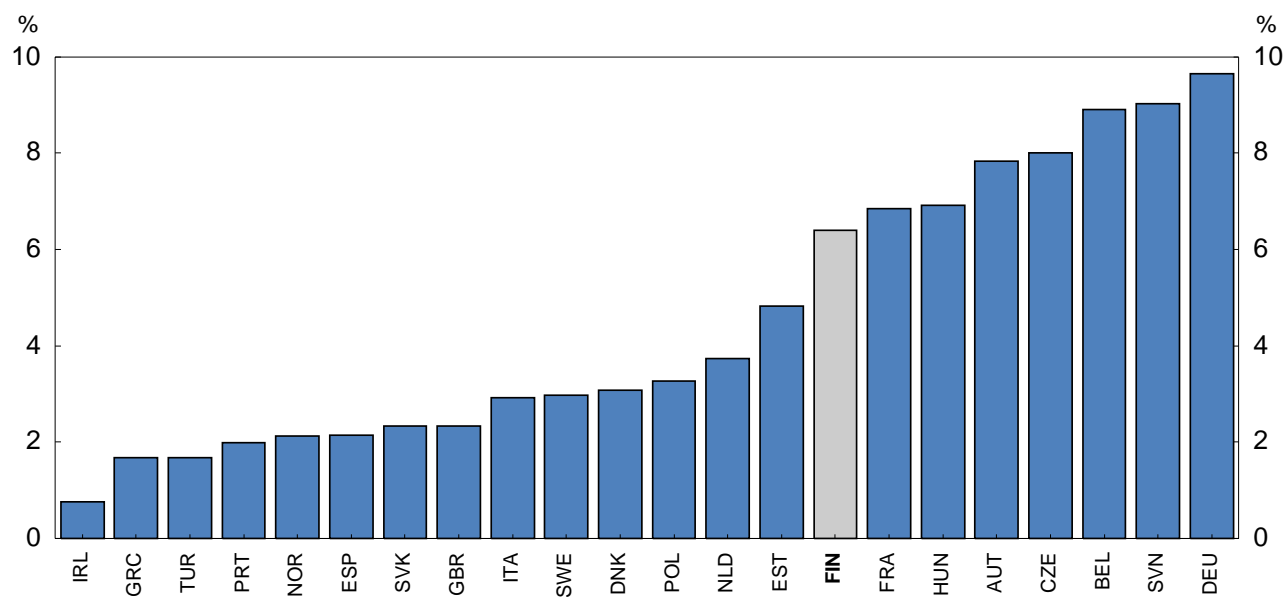

1. Percentage of workers over 55 years old who report having been subject to age discrimination at work. Source: European Working Conditions Survey, 2010.

Strict employment protection legislation (EPL) has two opposite impacts on hiring and firing older workers. On the one hand, it may help to keep people at work because it increases the cost of dismissals. On the other hand, it raises the cost of hiring and as a consequence may reduce the number of recruitments. Even if the net impact is not clear, some surveys have found that strict EPL tends to depress hiring and retention rates of older workers (Daniel and Siebert, 2004 and OECD, 2006).

The employability of workers should also be enhanced through lifelong training. As a result of the ongoing evolution of technology and the continuing shift from manufacturing to services, job requirements are evolving rapidly. This means that workers increasingly need to acquire new skills and upgrade existing ones, for which access to lifelong training is crucial. This would help workers adapt to new tasks and technology and can help them shift from arduous jobs to less exacting work after a certain age.

According to PIAAC, more than 1.7 million Finnish adults participate in adult education each year and a growing number participate in further vocational education and apprenticeship training (Ministry of Education and Culture, 2010). Moreover, for each level of literacy proficiency, the proportion of adults participating in training is higher in Finland than in the average of countries for which data are available. Nonetheless, as in other countries, adults with low literacy levels participate less than those with higher levels. Thus, efforts are needed to develop training for people with lower literacy levels, who are often also those who have not completed upper secondary education. Conflict with the work schedule is cited as the main obstacle to participation in training by $17 \%$ of the respondents aged 55 to 64 in the EU Adult Education Survey, somewhat more than in other Nordic countries (11\% in Sweden and Norway) (Eurostat, 2011). Accordingly, training during working hours should be promoted.

In 2003-09, the Noste Programme was implemented to raise the level of education among adult and older workers. Among the working age population, around $7.3 \%$ of people were involved regularly in vocational education and training and $5.6 \%$ obtained some qualification. The objective of $10 \%$ involvement was not attained and it is therefore important that such a programme can continue to be active in order to help keep older people at work. Apart from the Noste Programme, education and training of the unemployed have also been enhanced by supporting self-motivated training from 2010 onwards. The 
reform combines different categories of financial support to the unemployed during education and training, allowing them to choose more freely the sort of training they wish to attend (OECD, 2012d).

\section{Lowering barriers from employee's side}

Improving the financial incentives to stay at work is not enough to keep people in the workforce. Their working conditions (e.g. working time, workplaces) should also be adapted. Indeed, poor working conditions may lead people to retire as soon as they reach the minimum pension age. According to the European Working Conditions Survey 2010, more than 55\% of Finnish men aged 50-64 are exposed to unpleasant working conditions, 10 percentage points above the (unweighted) average of countries for which data are available. The share is around $40 \%$ for women of the same age, slightly below average (Figure 14). Even if such surveys give only a partial view of overall working conditions, they nevertheless stress the importance of improving the working environment of older workers.

In the same survey, between 25 and 30\% of people aged 50-64 considered that their work affects their health. In particular, mental health at work is an increasing problem in most OECD countries. In Finland, mental disorders and particularly depression, have accounted for an increasing share of disability pensions since the mid-1990s and are now the leading cause of disability benefit claims. The number of people retiring due to depression almost doubled after the mid-1990s, in part reflecting changes in the living, working and psychosocial environment. However, during the past four years, depression-related work disability has been declining, mainly thanks to cooperation between different actors and the dissemination of best practices (Honkonen et al., 2012). Nevertheless, the economic cost of depression-related disability remains high (OECD, 2014).

The government, recognising the overlap between mental illness and incapacity for work, has run the Masto project (2007-11) to prevent depression and depression-related work disability by tackling mental health problems at an early stage (OECD, 2014). The main themes included in the project were the promotion of well-being at work, various activities to prevent depression, early recognition and treatment, and the rehabilitation and return to work of people recovering from depression. The Masto project also included a nationwide tour that helped to reach managers and occupational safety and health personnel and provided information on the manifestation of depression and its impact on working lives.

More generally, lifelong health prevention can improve employability. It is widely available to the working population and especially people aged 45 and over. Through the so-called "age bus stop" in the occupational health centres in some municipalities, a full medical screening is provided free of charge. This allows the early recognition of diseases that are not conspicuous due to obvious symptoms. While such services used to be available only to employees, some projects started to provide occupational health services to the unemployed in order to maintain their employability and lower the cost of bringing them back into employment (von Werder and Thum, 2013). 
Figure 14. Unpleasant working conditions by age and gender ${ }^{1}$
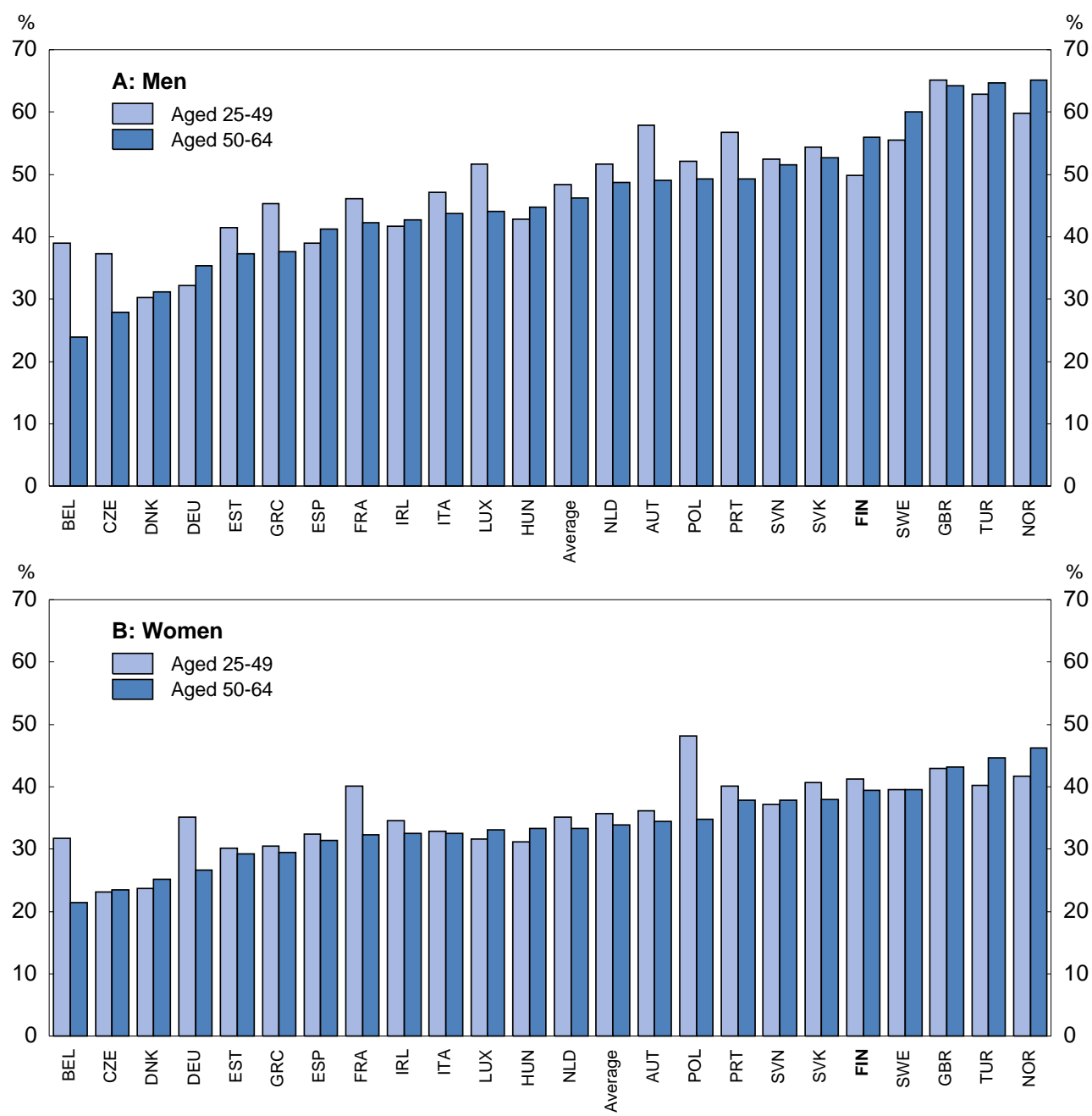

1. Workers were classified as experiencing unpleasant working conditions if they reported that for between around half to all of the time they were exposed in their main job to at least one of the following: vibrations from hand tools or machinery; noise so loud that you would have to raise your voice to talk to people; high temperatures which make you perspire even when not working; low temperatures whether indoors or outdoors; breathing in smoke, fumes, power or dust; breathing in vapours such as solvents and thinners; handling or being in skin contact with chemical products or substances; tobacco smoke from other people; handling or being in direct contact with materials which can be infectious.

Source: European Working Conditions Survey, 2010.

Flexibility in the workplace would facilitate labour market attachment. Around a third of workers aged over 50 would prefer working fewer hours, in line with the EU average. The incidence of part-time work among people aged 55-64 is slightly lower than the OECD average. For men it is 4 percentage points higher than the OECD average, while for women it is 10 percentage points lower. Even if Finland registers the highest proportion of companies providing flexible-time arrangements in the European Union, such arrangements still seem insufficient for older people. 


\section{Increasing labour force participation among other groups}

\section{A high tax wedge on labour hinders labour participation}

Labour force utilisation should also be enhanced for other segments of the labour market and overall disincentives reduced. The Finnish tax wedge is high by OECD standards, higher than in Denmark and Norway and around the same level as in Sweden (Figure 15). The labour tax wedge should be reduced and the efficiency of the tax structure improved. The revenue loss due to lowering labour taxation could be offset with higher indirect taxes.

Figure 15. Tax wedge in $2012^{1}$

As a percentage of labour costs

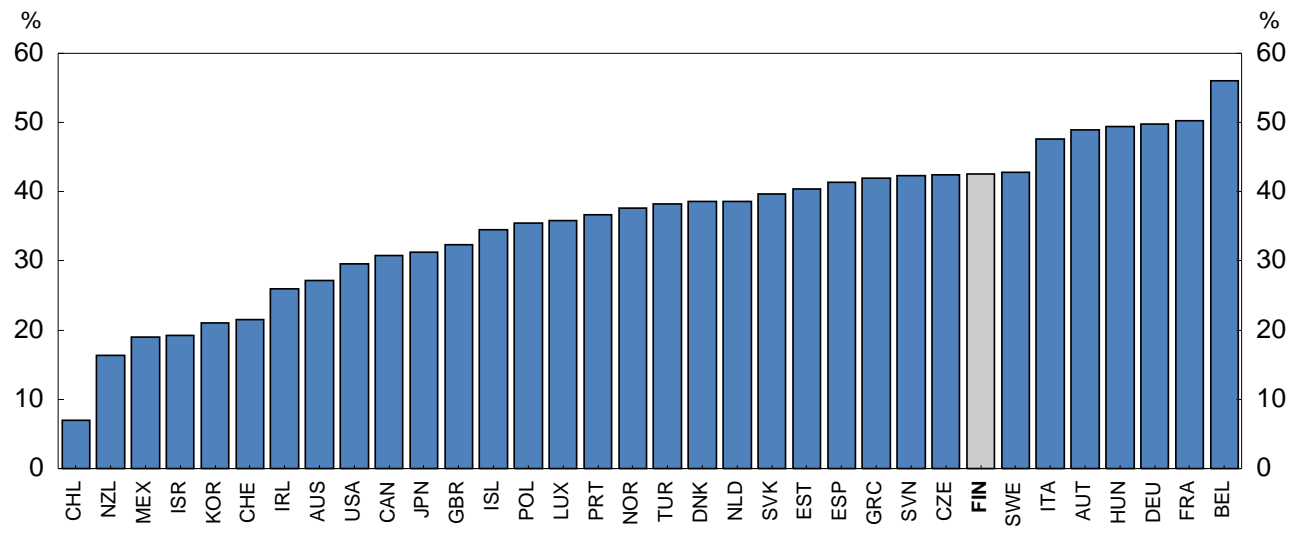

1. Single individual without children at the income level of the average worker.

Source: OECD, Taxing Wages 2013.

\section{Youth, childbearing age women and long-term unemployed participation rates should be enhanced}

Active labour market policies should be strengthened as insufficient activation of unemployed workers and high unemployment benefits are holding back employment. As from 2013, youth and recent graduates under the age of 30 unemployed for more than three months are guaranteed a tailored response from the employment offices. The responsibility of employment services is being shifted to municipalities after 12 months of unemployment, with individual follow-up and monitoring, in some pilots. Active labour market policies should continue to adjust so that activation takes place earlier and replacement rates should be reduced and tapered off throughout the unemployment spell (OECD, 2010).

Labour force participation of women in childbearing age should be encouraged as its low level has negative consequences on career prospects and pay. The Finnish family policy model provides ample support to parents with young children through paid parental-leave, home care leave and subsidised preschool until children go to primary school at age seven. This has contributed to a female employment rate of $67.5 \%$ in 2011 , well above the OECD average of $56.5 \%$. However, at $20 \%$ the gender pay gap is above the $16 \%$ OECD average (OECD, 2012e). The OECD Gender Initiative showed that periods of leave beyond two years reduce female employment and increase the gender pay gap, and the recent proposal to split the home care leave between the two parents evenly should therefore contribute to increase the employment rate of childbearing age women. 
Long-term unemployment should also be tackled in order to increase the overall employment rate. In contrast with the OECD average and the other Nordic countries, Finnish long-term unemployment has decreased in the past decade. Nonetheless at more than $20 \%$ of total unemployment in 2012 for people aged 15 and above, it is still higher than in Norway and Sweden. This is true especially for prime-age and older workers. Higher levels of qualification facilitate integration into the labour market and increase the productivity of workers. The government plans to increase the compulsory school leaving age from 16 to 17. This should improve the employability of youth and thereby reduce the duration of unemployment spells, provided education programmes fit student and labour market requirements. Furthermore, the Government has announced measures to reduce structural unemployment, such as strengthening employment services, developing a new electronic monitoring system for employment plans, bringing in earlier activation, tightening job-search requirements, enhancing work incentives through adjustments to the welfare system and making vocational training more flexible (Government of Finland, 2013).

\section{More accommodative immigration policies would help cope with labour market shortages}

Besides the lifting of residents' labour force participation, immigration could provide additional resources. While net immigration has increased recently, it is still relatively low by international standards especially compared with the other Nordic countries. Moreover, the share of foreign-born workers in recruitment has been low since 2008. This leaves room to encourage immigration for employment reasons and to implement more accommodative policies.

Finland has already launched several programmes to promote immigration and enhance integration, notably the Future of Migration 2020 Strategy. This comprehensive programme aims at anticipating the volume and nature of immigration required by Finland, and its impact on Finnish society. It has a number of key objectives: managing the labour market; ensuring equal rights for all employees; improving employment opportunities for people from an immigrant background; pursuing a more successful integration policy; a faster processing of asylum applications; and fighting discrimination. The preparation, co-ordinated by the Ministry of the Interior, involves a wide range of stakeholders, including municipalities, labour market organisations, the church and immigrant groups. Integration is also included in the Future of Migration 2020 Strategy which aims, among other things, at making integration policies more effective, increasing immigrants' employment rates and intensifying anti-discrimination efforts. Furthermore, a specific Integration Act entered into force in Finland in September 2011 followed by the adoption, in June 2012, of the Government Integration Programme for 2012-15. All these programmes should enhance the participation of migrants in the Finnish economy. Immigration policies should also avoid discouraging foreign students from staying to work in Finland.

While, as seen above, ageing will create pressure on the supply side of the labour market, it will also create new expectations on the demand side. Indeed, with the growing number of older people in the population, the demand for carers will increase. There are several ways to tackle shortages in the social care sector, particularly for long-term care (e.g. by recruiting LTC workers from underrepresented or inactive populations, for instance retired elderly people, unemployed populations, volunteers, or groups traditionally underrepresented in the LTC workforce such as men) (Fujisawa and Colombo, 2009). Finland is one of the countries reporting LTC workforce shortages alongside Spain, Austria, Canada and Italy. Current immigration policies should adapt to better respond to the growing demand for LTC labour.

\section{Ageing also creates new opportunities}

Ageing should not be seen only as a burden, as it can also create new opportunities. Innovation for an ageing society offers the prospect of new market opportunities and new growth industries (OECD, 2012c). As mentioned above, Finland has experienced an increase in the prevalence of dementia as the very old population increased. Such trends will require innovation to help the elderly stay as healthy, autonomous 
and active as possible. Indeed it will be important to harness the potential of information and communications technologies to develop new products and services to enhance the elderly's autonomy and keep them active in social, economic and cultural life. Technology already helps slow down the evolution of dependency. It participates in the prevention of pathologies by providing drugs or vaccines and in the restoration of physiological status after a health shock (e.g. prostheses and implants).

Moreover, information and communication technologies can facilitate social communication (via phone, internet, etc.), improve safety and make the home environment easier to manage. Since the 1990s, the proportion of older people in institutional care has declined steadily, in favour of service housing (OECD, 2012b). Technology is essential in this evolution, which can generate well-being gains for the elderly and substantial savings, as institutional care is very expensive. Finnish firms have developed telecare devices, which connect people in need of care to social services. For example, an intelligent watch sends an alarm if it detects a significant fall in its user's activity. Home tele-health allows remote monitoring of health parameters, such as blood glucose levels. Smart homes include many systems which enable independent life for older people (European Commission, 2010). Finland is marketing these services abroad and developing them further in international cooperation. For example, the Sendai-Finland Wellbeing Center is a joint venture promoted by Japanese and Finnish public institutions, which combines care and research and development (Fujita and Hill, 2011). It brings Finnish LTC organisation and technology to Japan. Furthermore, it is at the heart of a health, well-being and LTC cluster, where private companies and universities from both countries are involved in developing innovative technologies to improve the well-being of an ageing population. Such cooperation offers great opportunities for Finnish companies to expand in a high-growth market.

\section{Box 4. Recommendations on pension, health and labour market reforms}

\section{Key recommendations}

Increase the minimum pension age gradually and link the pension age and benefits, in combination, to life expectancy.

End part-time pensions and the extended period of eligibility to unemployment benefits for older people. Access to disability pensions should be based on medical reasons only.

Continue to promote lifelong training to help people stay in work as they age.

Strengthen active labour market policies to improve the labour force participation of youth, women of childbearing age and the long-term unemployed.

\section{Further recommendations}

Reduce fragmentation of health services and improve coordination and incentives to achieve a better balance between primary and specialised care (for more details, see the special chapter on health care in the 2012 OECD Economic Survey of Finland).

Age discrimination should continue to be tackled, notably via information campaigns. 


\section{BIBLIOGRAPHY}

André, C. and C. García (2014), "Local Public Finances and Municipal Reform in Finland”, OECD Economics Department Working Papers, No.1121, OECD Publishing.

Barr, N. (2012), “The Pension System in Finland: Adequacy, Sustainability and System Design”, Finnish Centre for Pensions, Helsinki.

Blanchflower D. and A. Oswald (2007), “Is Well-Being U-Shaped Over The Life Cycle?”, NBER Working Paper, No. 12935.

Bloom, D., D. Canning and G. Fink (2011), "Implications of Population Aging for Economic Growth", Program on The Global Demography of Aging Working Paper, No. 64.

Braconier, H. (2010), "Coping with the Job Crisis and Preparing for Ageing: The Case of Finland", OECD Economics Department Working Papers, No. 777, OECD Publishing.

Crépon, B. and P. Aubert (2003), "Productivité et salaire des travailleurs âgés", Economie et Statistique, No. 368.

Daniel, K. and W.S. Siebert (2004), "Does Employment Protection Reduce the Demand for Unskilled Labor?”, IZA Discussion Papers, No. 1290.

D'Addio, A., M.Keese and E. Whitehouse (2010), "Population Ageing and Labour Markets", Oxford Review of Economic Policy, Vol. 26, No. 4.

De la Maisonneuve, C. and J. Oliveira Martins (2013), "A Projection Method for Public Health and LongTerm Care Expenditures”, OECD Economics Department Working Papers, No. 1048, OECD Publishing.

Duval, R. (2003), "The Retirement Effects of Old-Age Pension and Early Retirement Schemes in OECD Countries", OECD Economics Department Working Papers, No. 370, OECD Publishing.

European Commission (2010), "ICT \& Ageing, European Study on Users, Markets and Technologies", Final Report, January. Report prepared by Empirica and WRC on behalf of the European Commission, Directorate General for Information Society and Media.

European Commission (2012a), The 2012 Ageing Report: Economic and Budgetary Projections for the EU-27 Member States, 2010-2060, Brussels.

European Commission (2012b), “Active Ageing”, Special Eurobarometer 378.

Eurostat (2011), Adult Education Survey.

Finnish Centre for Pensions (2013), Adjusting the Finnish Pension System to Increases in Life Expectancy: Report of the Pension Panel (in Finnish).

Forma, L., P. Rissanen, M. Aaltonen, J. Raitanen and M. Jylhä (2011), "Dementia as a Determinant of Social and Health Service Use in the Last Two Years of Life 1996-2003", BMC Geriatrics, Vol. 11.

Fujisawa, R. and F. Colombo (2009), "The Long-term Care Workforce: Overview and Strategies to Adapt Supply to a Growing Demand", OECD Health Working Paper, No. 44, OECD Publishing. 
Fujita, K. and R. Hill (2011), “Industry Clusters and Transnational Networks: Japan's New Directions in Regional Policy", in: B.G. Park, R. Hill and A. Saito (eds), Locating Neoliberalism in East Asia: Neoliberal Spaces in Asian Developmental States, Wiley-Blackwell.

Government of Finland (2013), Government Decision on Implementing the Structural Policy Programme, November.

Hellerstein, J. and D. Neumark (2004), "Production Function and Wage Equation Estimation with Heterogeneous Labor: Evidence from a New Matched Employer-Employee Data Set", NBER Working Paper, No. 10325.

HelpAge International (2013), The Global AgeWatch Index: Insight Report.

Honkonen T., M. Virtanen and K. Husman, "Prevention of depression: What kind of action is needed to prevent disability?", Työterveyslääkäri 2012; 1: 82-87 (in Finnish).

Johansson, Å., Y. Guillemette, F. Murtin, D. Turner, G. Nicoletti, C. de la Maisonneuve, P. Bagnoli, G. Bousquet and F. Spinelli (2013), "Long-Term Growth Scenarios", OECD Economics Department Working Papers, No. 1000, OECD Publishing.

Kerdrain, C., I. Koske and I. Wanner (2010), “The Impact of Structural Policies on Saving, Investment and Current Accounts", OECD Economics Department Working Papers, No. 815, OECD Publishing.

Määttänen, N. (2013), "Pension policy reform options, stochastic evaluation of the life-cycle model" in Lassila, J, Määttänen, N. ja Valkonen T., "Tying retirement age to life expectancy - what happens to working careers and income distribution?", Finnish Centre for Pensions, Reports/ ETLA B 258, 05/2013 (in Finnish).

Mahlberg, B., I. Freund, J.C. Cuaresma and A. Prskawetz (2013), “Ageing, Productivity and Wages in Austria", Labour Economics, Vol. 22, pp. 5-15.

Ministry of Education and Culture (2010), "Noste Programme 2003-2009: Final Report", Reports of the Ministry of Education and Culture 2010:8, Helsinki.

Ministry of Social Affairs and Health (2013a), "National Memory Programme 2012-2020, Creating a 'Memory friendly' Finland", Reports and Memorandums of the Ministry of Social Affairs and Health 2013:9, Helsinki.

Ministry of Social Affairs and Health (2013b), "Peer Review: eHealth Strategy and Action Plan of Finland in a European Context", Reports and Memorandums of the Ministry of Social Affairs and Health 2013:11, Helsinki.

Modigliani, F. and A. Ando (1963), "The Life Cycle Hypothesis of Saving: Aggregated Implications and Tests", American Economic Review, Vol. 53, No. 1.

Myrskylä, M., T. Leinonen and P. Martikainen (2013), "Life Expectancy by Labor Force Status and Social Class: Recent Period and Cohort Trends and Projections for Finland", Finnish Centre for Pensions, Working Papers No. 02/2013.

New Economics Foundation (2013), National Accounts of Well-being, London.

OECD (2004), Ageing and Employment Policies: Finland 2004, OECD Publishing. 
OECD (2006a), Live Longer, Work Longer, OECD Publishing.

OECD (2006b), OECD Economic Surveys: Finland, OECD Publishing.

OECD (2010), OECD Economic Surveys: Finland, OECD Publishing.

OECD (2011), Pensions at a Glance 2011: Retirement-income Systems in OECD and G20 Countries, OECD Publishing.

OECD (2012a), OECD Pensions Outlook 2012, OECD Publishing.

OECD (2012b), OECD Economic Surveys: Finland, OECD Publishing.

OECD (2012c), OECD Science, Technology and Industry Outlook 2012, OECD Publishing.

OECD (2012d), “OECD Thematic Follow-Up Review of Policies to Improve Labour Market Prospects for Older Workers, Finland", www.oecd.org/els/employment/olderworkers.

OECD (2012e), Closing the Gender Gap: Act Now, OECD Publishing.

OECD (2013a), Pensions at a Glance 2013: OECD and G20 Indicators, OECD Publishing.

OECD (2013b), OECD Skills Outlook 2013: First Results from the Survey of Adult Skills, OECD Publishing.

OECD (2013c), OECD Economic Outlook, Vol. 2013/1, OECD Publishing.

OECD (2013d), Economic Policy Reforms 2013: Going for Growth, OECD Publishing.

OECD (2014), Mental Health Analysis Profiles: Finland, forthcoming.

Prime Minister's Office (2011), "Longer working lives - Options for the Occupational Pension Schemes", Report of the Task Force on Working Lives", 4/2011 (in Finnish).

Sheiner, L., D. Sichel and L. Slifman (2007), "A Primer on the Macroeconomic Implications of Population Aging”, Finance and Economics Discussion Series, No. 2007-01, Divisions of Research \& Statistics and Monetary Affairs, Federal Reserve Board, Washington, D.C.

Skirbekk, V. (2003), “Age and Individual Productivity: A Literature Survey”, Max Planck Institute for Demographic Research Working Paper, No. 2003-028, Rostock.

Statistics Finland (2009),www.stat.filtil/ksyyt/2009/ksyyt_2009_2010-12-17_tie_001_en.html.

Van Erp, F., N. Vermeer and D. van Vuuren (2013), "Non-Financial Determinants of Retirement”, $C P B$ Discussion Paper No. 243.

Van Ours, J.C. and L. Stoeldraije (2010), “Age, Wage and Productivity”, IZA Discussion Paper, No. 4765.

Von Werder, M. and A-E. Thum (2013), "Extending Working Life in Finland", Centre for European Policy Studies Working Document, No. 387, Brussels. 
ECO/WKP(2014)16

\section{WORKING PAPERS}

The full series of Economics Department Working Papers can be consulted at www.oecd.org/eco/workingpapers

1119. Making the most of skills in Denmark

(June 2014) by Stéphanie Jamet and Vincent Koen

1118. Trade specialisation and policies to foster competition and innovation in Denmark

(June 2014) by Müge Adalet McGowan

1117. Policies for making the Chilean labour market more inclusive

(June 2014) by Aida Caldera Sanchez

1116. Spillover effects from exiting highly expansionary monetary policies

(May 2014) by Łukasz Rawdanowicz, Romain Bouis, Jérôme Brezillon, Ane Kathrine Christensen and Kei-Ichiro Inaba

1115. Economic policies and microeconomic stability: a literature review and some empirics

(April 2014) by Paula Garda and Volker Ziemann

1114. How to improve Israel's health-care system

(April 2014) by Philip Hemmings

1113. How to improve taxes and transfers in Israel

(April 2014) by Philip Hemmings

1112. New evidence on the determinants of industrial specialisation

(April 2014) by Asa Johansson and Eduardo Olaberria

1111. Economic growth from the household perspective: GDP and income distribution developments across OECD countries

(April 2014) by Orsetta Causa, Sonia Araujo, Agnès Cavaciuti, Nicolas Ruiz and Zuzana Smidova

1110. Would a growth slowdown in emerging markets spill over to high-income countries? A quantitative assessment (April 2014) By Patrice Ollivaud, Elena Rusticelli and Cyrille Schwellnus

1109. Short-term indicator models for quarterly GDP growth in the BRIICS: A small-scale bridge model approach

(April 2014) by Thomas Chalaux and Cyrille Schwellnus

1108. The prudential regulation of financial institutions: why regulatory responses to the crisis might not prove sufficient

(March 2014) by William R. White

1107. OECD forecasts during and after the financial crisis: a post mortem

(March 2014) by Nigel Pain, Christine Lewis, Thai-Thanh Dang, Yosuke Jin and

Pete Richardson 
1106. Fairly sharing the social impact of the crisis in Greece

(January 2014) by Vassiliki Koutsogeorgopoulou, Manos Matsaganis, Chrysa Leventi and Jan-David Schneider

1105. Dividing the pie in Brazil: income distribution, social policies and the new middle class (January 2014) by Jens M. Arnold and João Jalles

1104. New indicators of competition law and policy in 2013 for OECD and non-OECD countries (December 2013) by Enrico Alemani, Caroline Klein, Isabell Koske, Cristiana Vitale and Isabelle Wanner

1103. The effect of government debt, external debt and their interaction on OECD interest rates (December 2013) by David Turner and Francesca Spinelli

1102. The state of the banking sector in Europe

(December 2013) by Dirk Schoenmaker and Toon Peek

1101. Getting Irish youth on the job track

(December 2013) by Alberto González Pandiella

1100. New econometric estimates of long-term growth effects of different areas of public spending (December 2013) by Omar Barbiero and Boris Cournède

1099. Cross-country spillovers from fiscal consolidations

(December 2013) by Antoine Goujard

1098. Informal employment in Russia: definitions, incidence, determinants and labour market segmentation

(December 2013) by Hartmut Lehmann and Anzelika Zaiceva

1097. Capacity needs in the automobile industry in the short- to medium run (November 2013) by Caroline Klein and Isabell Koske

1096. Environmental policies and productivity growth - a critical review of empirical findings (November 2013) by Tomasz Koźluk and Vera Zipperer

1095. Green growth challenges and the need for an energy reform in Mexico (November 2013) by Carla Valdivia de Richter

1094. From bricks to brains: increasing the contribution of knowledge-based capital to growth in Ireland

(November 2013) by David Haugh

1093. China's march to prosperity: reforms to avoid the middle-income trap (November 2013) by Vincent Koen, Richard Herd and Sam Hill

1092. Multi factor productivity with natural capital

(November 2013) by Nicola Brandt, Paul Schreyer and Vera Zipperer

1091. Growth-promoting policies and macroeconomic stability

(November 2013) by Douglas Sutherland and Peter Hoeller 